\title{
Characterisation of manganese peroxidase and laccase producing bacteria capable for degradation of sucrose glutamic acid-Maillard reaction products at different nutritional and environmental conditions
}

\author{
Vineet Kumar ${ }^{1} \cdot$ Ram Chandra $^{1}$
}

Received: 20 July 2017 / Accepted: 27 January 2018 / Published online: 2 February 2018

(c) The Author(s) 2018. This article is an open access publication

\begin{abstract}
Maillard reactions products (MRPs) are a major colorant of distillery effluent. It is major source of environmental pollution due to its complex structure and recalcitrant nature. This study has revealed that sucrose glutamic acid-Maillard reaction products (SGA-MRPs) showed many absorption peaks between 200 and $450 \mathrm{~nm}$. The absorption maximum peak was noted at $250 \mathrm{~nm}$ in spectrophotometric detection. This indicated the formation of variable molecular weight Maillard products during the SGA-MRPs formation at high temperature. The identified aerobic bacterial consortium consisting Klebsiella pneumoniae (KU726953), Salmonella enterica (KU726954), Enterobacter aerogenes (KU726955), Enterobacter cloaceae (KU726957) showed optimum production of $\mathrm{MnP}$ and laccase at 120 and $144 \mathrm{~h}$ of growth, respectively. The potential bacterial consortium showed decolourisation of Maillard product up to $70 \%$ in presence of glucose (1\%), peptone $(0.1 \%)$ at optimum $\mathrm{pH}(8.1)$, temperature $\left(37^{\circ} \mathrm{C}\right)$ and shaking speed $(180 \mathrm{rpm})$ within $192 \mathrm{~h}$ of incubation. The reduction of colour of Maillard product correlated with shifting of absorption peaks in UV-Vis spectrophotometry analysis. Further, the changing of functional group in FT-IR data showed appearance of new peaks and GC-MS analysis of degraded sample revealed the depolymerisation of complex MRPs. The toxicity evaluation using seed of Phaseolus mungo L. showed reduction of toxicity of MRPs after bacterial treatment. Hence, this study concluded that developed bacterial consortium have capability for decolourisation of MRPs due to high content of MnP and laccase.
\end{abstract}

Keywords Melanoidins $\cdot$ Manganese peroxidase $\cdot$ Laccase $\cdot$ Metabolites $\cdot$ GC-MS analysis

\section{Introduction}

Melanoidins are complex, dark coloured, amino-carbonyl polymeric compounds with high molecular weight, formed by non-enzymatic browning Maillard reaction (MR) during several industrial processes (Hayase 2000; Echavarría et al. 2014; Bharagava and Chandra 2010). The major sources of

Electronic supplementary material The online version of this article (https://doi.org/10.1007/s11274-018-2416-9) contains supplementary material, which is available to authorized users.

Ram Chandra

rc_microitrc@yahoo.co.in; prof.chandrabbau@gmail.com

1 Department of Environmental Microbiology, School for Environmental Sciences, Babasaheb Bhimrao Ambedkar Central University, Vidya Vihar, Raebareli Road, Lucknow, Uttar Pradesh 226025, India melanoidins in environment are sugarcane-molasses based distilleries and fermentation industries all over the world. Due to its complex unknown organic pollutants and high total dissolved solids (TDS), the safe disposal of distillery waste is a paramount challenge for industrialist (Chandra and Kumar 2017). The toxicity of distillery waste is well documented in terrestrial and aquatic environment due to presence of heavy metals and recalcitrant organic compounds (Chandra et al. 2008a, b; Hemavanthi et al. 2015). The majority of molasses-based distilleries are located in tropical and subtropical regions of world and generate 12-15 liters of effluent per liter of alcohol production. Currently, there are more than 397 distilleries are operating in India producing approx. $3.25 \times 10^{10}$ liters of ethanol and generating $40.90 \times 10^{15}$ liters of effluent annually (AIDA 2016).

Various physico-chemical methods such as column filtration (Satyawali and Balakrishnan 2008), flocculation (Liang 
et al. 2009a), adsorption (Onyango et al. 2011), chemical precipitation or coagulation (Chandra and Singh 1999; Liang et al. 2009b), UV/ $\mathrm{H}_{2} \mathrm{O}_{2}$ treatment (Dwyer and Lant 2008) and ozone oxidation (Kim et al. 1985) has been reported for removal and decolourisation of distillery effluent, but these techniques are not feasible at large scale due to high cost and blockage of filtration devices. Moreover, due to high TDS it generates huge amount of toxic sludge and other secondary pollutants (Liang et al. 2009b; Chandra et al. 2008a). In addition, the conventional anaerobic digestion and activated sludge processes are effective in removing the biochemical oxygen demand (BOD) and chemical oxygen demand (COD) from effluent upto certain extent only. But, the color of distillery effluent converts darker with higher TDS after anaerobic treatment due to complexation of melanoidins. Therefore, extended aeration of distillery effluent does not change its physico-chemical properties even after aeration.

Hence, in recent years, the biological approaches with microbial decolourisation process of effluent for optimisation of various parameters at laboratory conditions have drawn attention of various workers world over to explore the feasible technology because it may lead eco-sustainable and cost effective alternative to chemical methods (Kaushik et al. 2010). Under biological treatment process using fungi such as Geotrichum candidum (Kim and Shoda 1999) Flavadon flavus (Raghukumar and Rivonkar 2001), Phanerochaete chrysosporium (Thakkar et al. 2006), Trametes sp. (Gonzalez et al. 2000), Coriolus hirsutus (Miyata et al. 2000), Pleurotus florida, Aspergillus flavus (Pant and Adholeya 2009a), Neurospora intermedia (Kaushik and Thakur 2013), Fusarium verticillioides (Pant and Adholeya 2009b) and yeast Citeromyces sp., Candida tropicalis (Tiwari et al. 2012), and Candida glabrate (Mahgoub et al. 2016) have been reported for melanoidins degradation using different category of melanoidins. The degradation and decolourisation of melanoidins by fungus has been reported more effective due to prevalence of ligninolytic enzymes, which metabolizes melanoidins as a sole carbon and nitrogen sources (Miyata et al. 2000; González et al. 2008). But, the large scale applications of these techniques have own constraint due to slow growth cycle, huge spore formation, low $\mathrm{pH}$ range (3.0-5.0), and adverse submerged aquatic environment for growth of fungus (Arimi et al. 2014). Therefore, bacteria are promising alternative for higher decolourisation due to its faster growth rate, higher environmental adaptability and high metabolizing capability of melanoidins by ligninolytic enzyme activity (Bharagava et al. 2009; Yadav et al. 2011). Some worker have reported the bacterial decolourisation and degradation of sugarcane molasses melanoidins as well as model melanoidins both (Kumar and Chandra 2006; Chandra et al. 2009; Bharagava and Chandra 2009). But, due to complex nature of melanoidins in sugarcane molasses with mixture of various other organic compounds it shows variable absorption range which makes more difficult to understand the mechanism of melanoidins decolourisation and characterization of its metabolic products. But, most of degradation/decolourisation process of molasses-melanoidins is reported at $475 \mathrm{~nm}$ only based on purified melanoidins absorption maxima through dialysis process with specific molecular weight, while the molasses-melanoidins contains mixture of Maillard products (i.e. initial, intermediate and advanced stages with variable molecular weight). Therefore, prior to attempting the degradation and decolourisation of distillery effluent, the degradation of model melanoidins with mixture of complex Maillard reaction products (MRPs) should be evaluated for its degradability. But, no any such study has been reported so far for assessment of melanoidins degradation as whole to assess the capability of bacterial consortium. Moreover, recent studies have revealed the preferential role of $\mathrm{MnP}$ for melanoidins depolymerisation followed by laccase induction in bacterial degradation (Yadav and Chandra 2012, 2013). The role of bacterial manganese peroxidase $(\mathrm{MnP})$ and laccase for melanoidins degradation is less reported.

Therefore, the main objective of this study was to investigate the $\mathrm{MnP}$ and laccase producing bacterial consortium capability for the degradation and decolourisation of complex sucrose glutamic acid-Maillard reaction products (SGA-MRPs), which are predominantly present in sugarcane juice composition which generate the complex of molasses melanoidins due to thermal degradation reaction at subsequent stage (Walford 1996; Eggleston and Vercellotti 2000). Further, the change in absorption peaks $(200-700 \mathrm{~nm})$ by $\mathrm{UV}-\mathrm{Vis}$ spectrophotometric analysis has been correlated for their structural changes and reduction in color by investigation through fourier transform-infrared spectroscopy (FTIR), high performance liquid chromatography (HPLC), and gas chromatography-mass spectrometry (GC-MS) analysis. Furthermore, to evaluate the stability of potential bacterial consortium at variable nutritional and environmental conditions was assessed for optimum degradation and decolourisation of SGA-MRPs. The reduction of toxicity after bacterial degradation was also evaluated by using seed germination test of Phaseolus mungo L.

\section{Materials and methods}

\section{Distillery sludge sample collection, isolation and screening of melanoidins tolerant, $\mathrm{MnP}$, and laccase producing bacterial strains}

The sludge sample was collected from the dumping site of $\mathrm{M} / \mathrm{s}$ Unnao Distilleries and Breweries, located in Unnao, Uttar Pradesh $\left(26^{\circ} 320^{\prime \prime} \mathrm{N}, 80^{\circ} 30^{\prime} 0^{\prime \prime} \mathrm{E}\right)$, India for isolation of potential bacterial strains. For isolation of bacterial strains, $10 \mathrm{~g}$ of sludge sample was transferred to a $250 \mathrm{~mL}$ 
Erlenmeyer flask containing $100 \mathrm{~mL}$ sterile GPM broth (g L ${ }^{-1}$; glucose $1 \%$, peptone $0.1 \%, \mathrm{MgSO}_{4} \cdot 7 \mathrm{H}_{2} \mathrm{O} 0.05 \%$, $\mathrm{K}_{2} \mathrm{HPO}_{4} 0.1 \%$ ). The flasks were incubated at $37 \pm 1{ }^{\circ} \mathrm{C}$ in a refrigerated incubator shaker (Orbitek, Scigenic Biotech, India) at $120 \mathrm{rpm}$ for 7 days. The flask containing the sample showing the decolourisation was selected. Subsequently, an aliquot $(1.0 \mathrm{~mL})$ was taken serially diluted in order of $10^{-2}, 10^{-3}, 10^{-4}, 10^{-5}$, and $10^{-6}$, then after diluted sample $(0.1 \mathrm{~mL})$ was spread on GPM agar medium plates. Further, the bacterial colonies showing clear zone on agar plates were purified on GPM agar plate by streak plate method.

To investigate, the bacterial tolerance on melanoidins purified bacterial strains were spread on pre-sterilised GPM agar medium plate amended with different concentration of molasses melanoidins (1000, 1500, 2000, 2500, 3000, and $\left.3500 \mathrm{mg} \mathrm{L}^{-1} \mathrm{w} / \mathrm{v}\right)$. Each plate was incubated at $37 \pm 1{ }^{\circ} \mathrm{C}$ for $48 \mathrm{~h}$ and observed for growth of tolerant bacterial colonies. The bacterial strains tolerant to high concentration of melanoidins were selected and screened for $\mathrm{MnP}$ and laccase activity by plate assay method. For enzyme screening, the substrate used for MnP (EC 1.11.1.13) was phenol red (Lobachemie, India) (Pangallo et al. 2007), while laccase (EC 1.10.3.2) activity was detected in presence of guaiacol (Sigma-Aldrich, St. Louis, MO, USA) as a substrate in B\&K agar medium containing $\left(\mathrm{g} \mathrm{L}^{-1}\right)$ dextrose $1 \%$, peptone $0.5 \%$, beef extract $0.3 \%, \mathrm{NaCl} 0.5 \%$, and $\mathrm{CuSO}_{4}(1 \mathrm{mM})$ (D'Souza et al. 2006). The conversion of dark pink to yellow colour indicated the presence of MnP activity and reddish brown colour zones in the medium indicated the presence of laccase activity.

\section{Identification of bacterial strains}

\section{Morphological and biochemical characterisation}

The isolated bacterial strains were identified based on morphological and biochemical characteristics by using the standard procedure described by Barrow and Feltham (2003).

\section{Molecular characterisation}

The isolated potential $\mathrm{MnP}$ and laccase producing bacterial strains were characterized by $16 \mathrm{~S}$ rRNA gene sequence analysis. The total genomic DNA from the overnight growth culture of bacterial consortium was extracted using the method described by Kapley et al. (2001). The PCR amplicon were electrophoresed through $1.2 \%(\mathrm{w} / \mathrm{v})$ agarose gel in $1 \times \mathrm{TAE}$ buffer using $1 \mathrm{~Kb}$ DNA ladder (Merck Biosciences, India), then visualized by staining with ethidium bromide. Finally, the amplified 16S rDNA gene amplicon were purified from gel using a PCR cleanup kit (Merck Biosciences, India) and sequenced using $1492 \mathrm{R}$ and $27 \mathrm{~F}$ eubacterial primer in an automated DNA sequencer. A phylogenetic tree was generated using the MEGA software (version 6.0) by the Neighbor-Joining method (Tamura et al. 2013).

\section{Maillard products decolourisation and degradation studies}

\section{Preparation and physico-chemical analysis of Maillard products}

SGA-MRPs were prepared following the method described by Bharagava et al. (2009). Briefly, 1.0 M sucrose, $1.0 \mathrm{M}$ glutamic acid, and $0.5 \mathrm{M}$ sodium carbonate were dissolved in $1.0 \mathrm{~L}$ of doubled distilled water and the $\mathrm{pH}$ of the reaction mixture was adjusted to 8.0 with $1 \mathrm{~N} \mathrm{NaOH}$. After this, the solution was refluxed at $110^{\circ} \mathrm{C}$ for $8 \mathrm{~h}$. The prepared SGA-MRPs were diluted to $10 \%$ of its original concentration using distilled water to obtain the OD $3.5 \pm 0.02$ at $250 \mathrm{~nm}$. This prepared SGA-MRPs solution was used for physicochemical and decolourisation studies. The physico-chemical parameters (i.e. color, $\mathrm{pH}, \mathrm{BOD}, \mathrm{COD}$, TDS, etc.) of SGAMRPs were analysed as per standard methods (APHA 2012).

\section{Construction of bacterial consortium for decolourisation studies}

A loopful pure culture of isolated bacteria strains IITRCS01, IITRCS06, IITRCS07, and IITRCS11 was transferred to a $50 \mathrm{~mL}$ modified GPM broth medium supplemented with $\mathrm{K}_{2} \mathrm{HPO}_{4}(0.1 \%), \mathrm{MgSO}_{4} \cdot 7 \mathrm{H}_{2} \mathrm{O}(0.05 \%)$ and molasses melanoidins $\left(1000 \mathrm{mg} \mathrm{L}^{-1}\right)$ and incubated for $24 \mathrm{~h}$ in continuous shaking condition $(125 \mathrm{rpm})$ at $37 \pm 1{ }^{\circ} \mathrm{C}$. After $24 \mathrm{~h}$, the equal volume of each bacterial strains containing cell density $3.1 \times 10^{4}$ cells $\mathrm{mL}^{-1}$ was used for preparation of different bacterial consortium. The bacterial strains IITRCS01, IITRCS06, IITRCS07, and IITRCS11 were taken in the various combinations i.e. in the ratio of 1:1:1:1, 1:2:1:1, 1:2:2:1, $1: 2: 2: 2,2: 1: 1: 2 ; 2: 2: 1: 1,2: 2: 2: 1$ and $2: 2: 2: 2$ for optimal decolourisation of SGA-MRPs.

\section{Decolourisation assay}

The decolourisation experiment was carried out in Erlenmeyer flasks $(250 \mathrm{~mL})$ containing $100 \mathrm{~mL}$ of previously prepared (as mentioned in "Maillard products decolourisation and degradation studies" section) sterile SGA-MRPs solution supplemented with (glucose $1 \%$, peptone $0.1 \%$, $\left.\mathrm{K}_{2} \mathrm{HPO}_{4} 0.1 \%\right)$ and $\mathrm{MgSO}_{4} \cdot 7 \mathrm{H}_{2} \mathrm{O}\left(0.05 \% \mathrm{~g} \mathrm{~L}^{-1}\right)$ and $1.0 \mathrm{~mL}$ of trace elements solution containing $\mathrm{CuSO}_{4} \cdot 5 \mathrm{H}_{2} \mathrm{O}$ $(0.003 \%), \mathrm{MnCl}_{2} \cdot 4 \mathrm{H}_{2} \mathrm{O}(0.001 \%), \mathrm{ZnSO}_{4} \cdot 7 \mathrm{H}_{2} \mathrm{O}(0.001 \%)$, and $\mathrm{CaCl}_{2} \cdot 2 \mathrm{H}_{2} \mathrm{O}(0.002 \%)$, and $\mathrm{pH}$ was adjusted to 7.0 with $1 \mathrm{~N} \mathrm{NaOH}$ (Bharagava et al. 2009). The flasks were inoculated with $1 \%(\mathrm{v} / \mathrm{v})$ over night grown culture of bacterial consortium (OD 0.24) and incubated at $37 \pm 1{ }^{\circ} \mathrm{C}$ under 
shaking flask condition $(125 \mathrm{rpm})$ for $192 \mathrm{~h}$. The decolourisation of SGA-MRPs was monitored by measuring the change in absorbance maxima of the melanoidins at $250 \mathrm{~nm}$ after scanning of absorbance maxima by using a UV-Vis spectrophotometer (Evoluation-201, Thermo Scientific, USA). Simultaneously, the un-inoculated flask contain same medium and condition was used as control. The \% decolorization was calculated as

Decolourisation (\%)

$$
=\frac{\text { initial absorbance }\left(\mathrm{A}_{0}\right)-\text { final absorbance }\left(\mathrm{A}_{1}\right)}{\text { initial absorbance }\left(\mathrm{A}_{0}\right)} \times 100
$$

\section{Optimisation of culture conditions for decolourisation and degradation of SGA-MRPs}

\section{Optimisation of nutritional parameters}

The effect of different carbon source viz. sucrose, fructose, glucose, xylose, lactose, and starch at $1.0 \%(\mathrm{w} / \mathrm{v})$ were evaluated for the SGA-MRPs decolourisation and degradation. In another experiment, different organic and inorganic nitrogen sources viz. peptone, beef extract, yeast extract, sodium sulphate, ammonium chloride and urea were added into the GPM medium at $0.5 \%(\mathrm{w} / \mathrm{v})$ concentration. The effect of carbon and nitrogen sources were optimised for decolourisation and degradation SGA-MRPs at different concentration viz. $0.1-1.0(\mathrm{w} / \mathrm{v})$.

\section{Optimisation of environmental conditions}

To evaluate the effect of different environmental conditions the same experiment was carried out at different temperature $\left(25-50{ }^{\circ} \mathrm{C}\right), \mathrm{pH}(4-12)$, and shaking speed (100-220 rpm).

\section{Evaluation of bacterial growth, biomass, and scanning electron microscopic (SEM) observation of bacterial consortium}

During decolourisation experiment, the optical density was continuously measured till $192 \mathrm{~h}$ at $12 \mathrm{~h}$ periodic interval by taking absorbance at $620 \mathrm{~nm}$ by UV-Vis spectrophotometer as the measurement of the bacterial cell growth. While the bacterial sample for biomass determination and SEM micrograph was collected from the flask after $144 \mathrm{~h}$ of incubation. First, the bacterial cells were centrifuged $(6500 \times g)$ for $10 \mathrm{~min}$ at $4{ }^{\circ} \mathrm{C}$, the pellets were washed thrice with distilled water to remove the attached medium contents. For bacterial biomass determination, the pellet was dried in an hot air oven at $80{ }^{\circ} \mathrm{C}$ until getting a constant dried weight reported in the form of dry cell mass $\left(\mathrm{g} \mathrm{L}^{-1}\right)$. For SEM micrograph, the bacterial cells were fixed with $1 \%(\mathrm{w} / \mathrm{v})$ glutaraldehyde in $0.1 \mathrm{M}$ phosphate buffer ( $\mathrm{pH}$ 7.2) for $2 \mathrm{~h}$ and washed again with distilled water. The fixed samples were then dehydrated through $25,50,75,95$ and $100 \%$ ethanol solutions in increasing concentration for $5 \mathrm{~min}$, at each step. The samples were then dried in critical point drier and coated with a thin conductive film of gold in a sputtering coater and observed under SEM (FEI Quanta 450, Hillsboro, USA).

\section{Estimation of MnP and lacasse activity}

To measure the ligninolytic activity during degradation, the bacterial degraded supernatant was obtained by centrifugation at $6500 \times g$ for $10 \mathrm{~min}$ at $4{ }^{\circ} \mathrm{C}$. The $\mathrm{MnP}$ and laccase activity was determined using the phenol red (Lobachemie, Mumbai, India) and guaiacol (Sigma-Aldrich, St. Louis, MO, USA), respectively as described earlier (Arora et al. 2002). The enzyme activity was expressed as international unit (IU), where $1 \mathrm{IU}$ represents the amount of enzyme that forms $1 \mu \mathrm{mol}$ of product per minute under standard assay conditions.

\section{UV-Vis and FT-IR spectroscopic analysis}

UV-Vis absorption spectra of the treated and untreated SGA-MRPs solution were recorded using a UV-Vis spectrophotometer in the wavelength range between 200 and $700 \mathrm{~nm}$ at room temperature. Further, FT-IR analysis of the sample was performed in range of $400-4000 \mathrm{~cm}^{-1}$ using a spectrophotometer (Nicolet ${ }^{\mathrm{TM}}$ 6700, Thermo Scientific, USA) in order to reveal the chemical nature of the SGAMRPs. The separated samples of SGA-MPs were mixed with potassium bromide $(\mathrm{KBr})$ to prepare the pellet for FT-IR analysis.

\section{Extraction and identification of various organic compounds}

The organic compounds present in treated and untreated SGA-MPs were extracted by ethyl acetate under acidic condition $(\mathrm{pH}<2.0)$ as previously described (Chandra and Kumar 2017). An aliquot of the concentrate was dissolved in $3.0 \mathrm{~mL}$ methanol, filtered through $0.22-\mu \mathrm{m}$ syringe filters and used for further HPLC and GC-MS analysis.

\section{HPLC analysis}

HPLC analysis was carried out using waters, 515 HPLC instrument equipped with a diode array detector system (1100 series, Agilent Technologies, USA) and reverse phase $\mathrm{C}_{18}$ column $(250 \times 4.6 \mathrm{~mm}, 5 \mu \mathrm{m}$ particle size $)$ by using the gradient of solvent A (Milli-Q water) and solvent $\mathrm{B}$ (acetonitrile with $0.1 \%$ TFA) (Merck, Germany) at a flow rate $0.4 \mathrm{~mL} \mathrm{~min}^{-1}$ for 60 . The detection was monitored at wavelength $250 \mathrm{~nm}$ (absorption maxima) to assess the 
decolourisation and degradation of Maillard products. $50 \mu \mathrm{L}$ of methanol extract was injected into the column by using a glass microsyringe (Agilent Technologies, USA).

\section{GC-MS analysis}

In GC-MS analysis, the extracted samples were derivatised with trimethylsilyl (TMS) as described by Chandra and Kumar (2017). An aliquot $(2.0 \mu \mathrm{L})$ of derivatised sample was injected in GC-MS (Trace GC Ultra Gas Chromatograph, Thermo Scientific, USA) equipped with a TriPlus auto sampler coupled to TSQ Quantum XLS triple quadrupole mass spectrometer (Thermo Scientific, USA). Separation was carried out on DB-5 MS capillary column (30-m length $\times 0.25 \mu \mathrm{m}$ I.D. $\times 0.25 \mathrm{~mm}$ film thickness of $5 \%$ phenyl and $95 \%$ methylpolysiloxane) with helium as the carrier gas at a flow rate of $1.1 \mathrm{~mL} \mathrm{~min}^{-1}$. The temperature of GC oven was programmed started from $65^{\circ} \mathrm{C}$ (hold for $2 \mathrm{~min}$ ), increased to $230{ }^{\circ} \mathrm{C}$ at a rate of $6{ }^{\circ} \mathrm{C} \mathrm{min}-1$ and finally reached to $290{ }^{\circ} \mathrm{C}$ (hold for $20 \mathrm{~min}$ ) at a rate of $10{ }^{\circ} \mathrm{C} \mathrm{min}-1$ increased. The transfer line temperature and ion source temperature were kept at 290 and $220^{\circ} \mathrm{C}$, respectively. The mass spectrum (MS) was operated in the positive electron ionization (+EI) mode at an electron energy of $70 \mathrm{eV}$ with a solvent delay of $7 \mathrm{~min}$. The MS was operated in full-scan mode from $\mathrm{m} / z, 45-800$. The detected organic compounds were identified by matching with the MS library NIST v. 1.0.0.12 available with instrument.

\section{Toxicity assessment of Maillard reaction products}

The toxicity effect of untreated and treated SGA-MRPs was studied on $P$. mungo L. seed germination using Petri dish method (Chandra and Kumar 2017). The seed germination parameters like germination percentage, germination index (GI), relative toxicity percentage, phytotoxicity percentage and stress tolerance index were calculated using the formula described earlier (Chandra and Kumar 2017; David Noel and Rajan 2015).

\section{Statistical data analysis}

All the experiment was carried out in triplicate and the results were presented as the mean of three independent observations. To confirm the variability of data obtained and validity of results, the mean concentration of various physico-chemical parameters of untreated and treated SGAMRPs was calculated by Student's $t$ test by using SPSS (version 17.0, Chicago, USA).

\section{Results}

\section{Isolation and screening of bacterial strains}

Twenty-seven morphologically distinct bacterial strains were isolated from distillery sludge. Only four bacterial isolates namely IITRCS01, IITRCS06, IITRCS07, and IITRCS11 could show the MnP activity by changing the deep orange to light yellow color at melanoidins $\left(800 \mathrm{mg} \mathrm{L}^{-1}\right)$ containing phenol red amended modified GPM agar plates, as well as laccase activity by developing a reddish brown color zone on $\mathrm{B} \& \mathrm{~K}$ agar plate during the screening of potential bacterial strains capable for growth on SGA-MRPs amended media. The screened bacterial strains also showed tolerance for growth on melanoidins amended GPM agar plate at $3500 \mathrm{mg} \mathrm{L}^{-1}$ concentration.

\section{Characterisation and identification of bacterial strains}

Screened bacterial strains IITRCS01, IITRCS06, IITRCS07, and IITRCS 11 showed several morphological and biochemical characteristics are mentioned in Bergey's manual of Systematic Bacteriology (Brenner et al. 2005). Further, the molecular identification of screened bacterial strains IITRCS01, IITRCS06, IITRCS07, and IITRCS11 showed specific amplification of a single band of around $1500 \mathrm{bp}$ of $16 \mathrm{~S}$ rRNA gene (Supplementary Fig. S1). The BLAST analysis of nucleotide sequence data of representative isolates was showed $100 \%$ sequence homology with Klebsiella pneumoniae (KU726952), Salmonella enterica (NR044372), Enterobacter aerogenes (NR024643), and Enterobacter cloaceae (KJ437492) found in the GenBank database. Hence, based on the sequence homology, the bacterial strain IITRCS01, IITRCS06, IITRCS07, and IITRCS11 were identified as K. pneumoniae (KU726953), S. enterica (KU726954), E. aerogenes (KU726955), E. cloaceae (KU726957), respectively. These bacterial species belonged to group Gammaproteobacteria. Further, the phylogenetic tree was showed the interrelationship of bacterial species with the most closely related genera inferred from sequences of the 16S rRNA gene as shown in Supplementary Fig. S2.

\section{Physico-chemical analysis}

The physico-chemical characteristics of untreated SGAMRPs showed dark brown in color at $\mathrm{pH}$ 6.9. In addition, the concentration of BOD (8641), COD $(11,586)$, TDS (1050.77), VS (457.83), and phenolics (110.56 $\left.\mathrm{mg} \mathrm{L}^{-1}\right)$ were found higher as shown in Table 1 . In contrast to above, the bacterial treated SGA-MRPs showed reduction 
Table 1 Physico-chemical analysis of sucrose-glutamic acid Maillard products

\begin{tabular}{llllll}
\hline Parameter & Untreated (control) & Bacterial treated & & Reduction (\%) & $\begin{array}{c}\text { Discharge permis- } \\
\text { sible limit (USEPA } \\
\text { 2002) }\end{array}$ \\
\cline { 2 - 5 } & & After 96 $\mathrm{h}$ & After 192 $\mathrm{h}$ & & - \\
\hline Color appearance & Dark brown & Dark brown & Light brown & - & - \\
pH & $6.9 \pm 0.0$ & $4.1 \pm 0.10^{\mathrm{b}}$ & $8.1 \pm 0.20^{\mathrm{a}}$ & -14.28 & 40.00 \\
BOD & $8641 \pm 160.33$ & $5472 \pm 1.04^{\mathrm{a}}$ & $2568 \pm 2.01^{\mathrm{a}}$ & 70.28 & 120.00 \\
COD & $11586 \pm 92.82$ & $4867 \pm 1.29^{\mathrm{a}}$ & $4201 \pm 3.11^{\mathrm{a}}$ & 63.74 & - \\
TDS & $1050.77 \pm 2.39$ & $997.1 \pm 1.01^{\mathrm{b}}$ & $687.92 \pm 2.90^{\mathrm{a}}$ & 34.53 & - \\
VS & $457.83 \pm 9.39$ & $254.24 \pm 1.11^{\mathrm{a}}$ & $113.41 \pm 1.12^{\mathrm{a}}$ & 75.22 & 750.00 \\
Phenolics & $110.56 \pm 1.40$ & $89.01 \pm 0.01^{\mathrm{b}}$ & $55.77 \pm 1.43^{\mathrm{a}}$ & 49.55 & \\
\hline
\end{tabular}

All values are mean $(\mathrm{n}=3) \pm \mathrm{SD}$ in $\mathrm{mg} \mathrm{L}^{-1}$ except $\mathrm{pH}$

$B O D$ biological oxygen demand, $C O D$ chemical oxygen demand, $T D S$ total dissolved solid, $V S$ volatile solids

Student's $t$ test (two tailed as compared with untreated sample) was performed, where

${ }^{a}$ Highly significant at $\mathrm{p}<0.001$

${ }^{\mathrm{b}}$ Significant at $\mathrm{p}<0.01$

in all physico-chemical parameters as shown in Table 1 . The colour of SGA-MRPs is dark brown which turned light brown after bacteria treatment. Initially, during degradation of SGA-MRPs the $\mathrm{pH}$ of medium was decreased to 4.1 , but after $192 \mathrm{~h}$ of bacterial growth the $\mathrm{pH}$ was gradually enhanced. However, a sharp reduction in BOD (2568), COD (4201), TDS (687.92), VS (113.41) and phenolics $\left(55.77 \mathrm{mg} \mathrm{L}^{-1}\right)$ was noted as shown in Table 1. All the physico-chemical parameters of treated SGA-MRPs were found significantly higher $(\mathrm{p}<0.001)$ that the untreated SGA-MRPs except for $\mathrm{pH}(\mathrm{p}<0.05)$.

\section{Effect of different carbon and nitrogen sources}

SGA-MRPs decolourisation was monitored by using different carbon sources at $1 \%(\mathrm{w} / \mathrm{v})$ concentration for $192 \mathrm{~h}$ of incubation, and the results are illustrated in Fig. 1a. It was observed that glucose was the best carbon source, allowing maximum decolourisation $(65.8 \%)$ at $1 \%(\mathrm{w} / \mathrm{v})$ concentration. The decolourising ability of bacterial consortium was tested at different concentration showed that the efficiency of consortium increase with increase in glucose concentration from 0.1 to $1 \%$ reaching maximum decolourisation $(65.8 \%)$ at $1.0 \%$. While in absence of glucose slow growth of bacterial consortium was noted. However, sucrose, xylose and lactose were found less effective than glucose showed decolourisation upto $63-61.2 \%$. Fructose was relatively poor co-substrate, aiding only $40 \%$ decolourisation.

The effect of different organic and inorganic nitrogen sources at a concentration of $0.5 \%(\mathrm{w} / \mathrm{v})$ along with glucose $(1.0 \% \mathrm{w} / \mathrm{v})$ showed that peptone was most effective organic nitrogen source which enhanced up to $72 \%$ decolourisation of Maillard products at $0.1 \%(\mathrm{w} / \mathrm{v})$ concentration (Fig. 1b). Further, increase in concentration of peptone resulted in continuous reduction in degradation capability of the developed bacterial consortium inhibited the decolourisation process. However, presence of other organic nitrogen sources i.e. beef extract, and yeast extract could show the SGA-MRPs decolorization upto 55-58\% only, while urea could shown the decolourisation upto $15 \%$, whereas inorganic nitrogen sources such as sodium sulphate and ammonium chloride could show the decolourisation upto 32, and $25 \%$, respectively.

\section{Effect of $\mathrm{pH}$, temperature and shaking speed}

The effect of variable $\mathrm{pH}$, temperature, shaking speed on Maillard products decolourisation showed that alkaline $\mathrm{pH}$ (8.1) was optimum for maximum solubility of Maillard products. Further, increase in $\mathrm{pH}$ inhibited the decolourisation process (Fig. 1c). Similarly, it was also observed that increase in temperature $\left(25-37^{\circ} \mathrm{C}\right)$ enhanced decolourisation of MRPs from 35 to $70 \%$ (Fig. 1d). While further, the increase in temperature up to $45^{\circ} \mathrm{C}$ adversely affected the growth and decolourisation ability of the bacterial consortium. Further, the shaking speed effect from 100 to $180 \mathrm{rpm}$ showed the optimum decolourisation by potential bacterial consortium at $180 \mathrm{rpm}$ as shown in Fig. 1c. The bacterial consortium showed better decolourisation and degradation of SGA-MRPs in ration of 1:1:1:1.

\section{Bacterial growth and biomass}

The periodic monitoring of bacterial growth curve and biomass showed maximum $\mathrm{OD}_{620}$ (2.49) and biomass $\left(5.15 \mathrm{~g} \mathrm{~L}^{-1} ; \mathrm{CFU} / \mathrm{mL} 28 \times 10^{6}\right)$ at $144 \mathrm{~h}$ incubation period during decolourisation process (Fig. 2; Supplementary Fig. S3). This indicated the most optimum condition for 


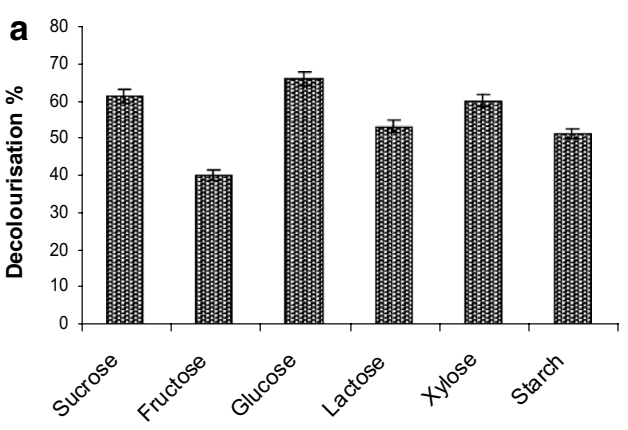

Different carbon source

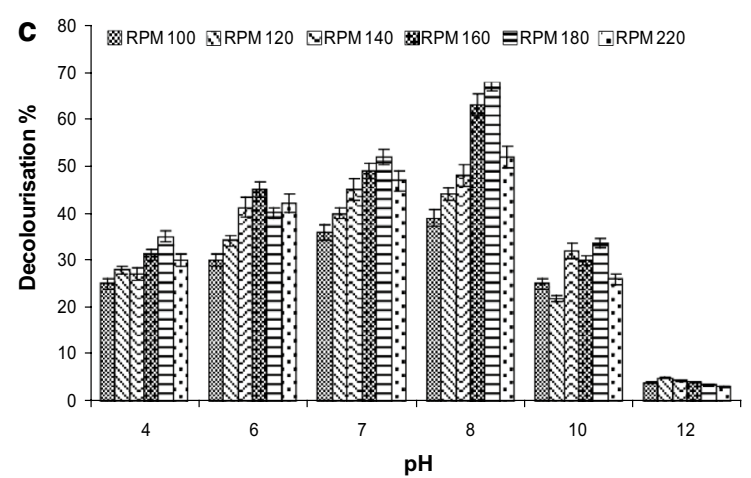

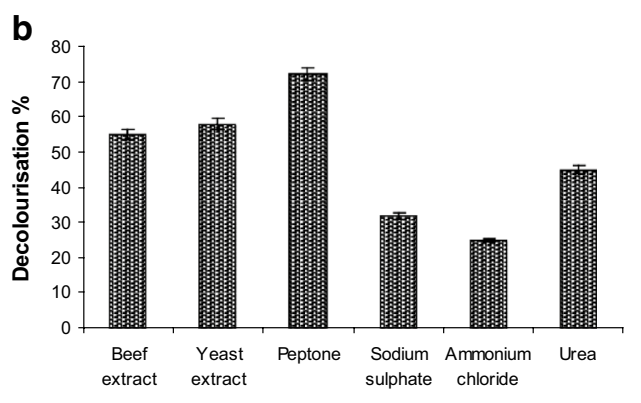

Different nitrogen source

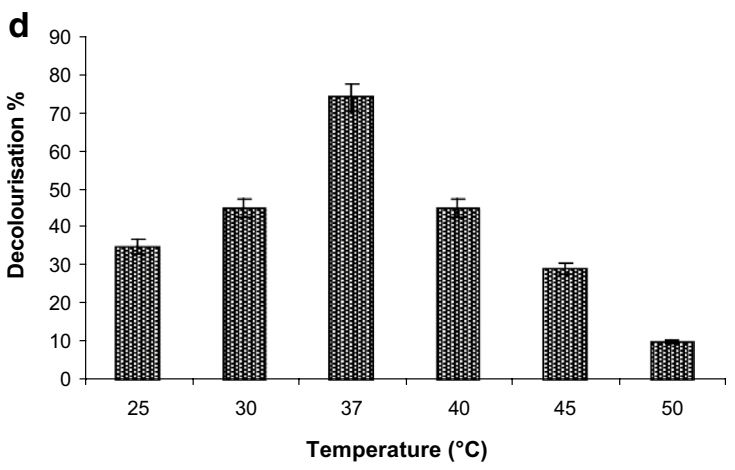

Fig. 1 Effect of different nutrient and environmental parameters on SGA-MRPs decolourisation. a Carbon source, $\mathbf{b}$ nitrogen source, $\mathbf{c}$ pH, and $\mathbf{d}$ temperature and shaking speed at $37{ }^{\circ} \mathrm{C}$ for $24-192 \mathrm{~h}$ incubation

Fig. 2 a Growth pattern and b scanning electron micrograph of developed bacterial consortium during degradation and decolourisation of SGA-MRPs

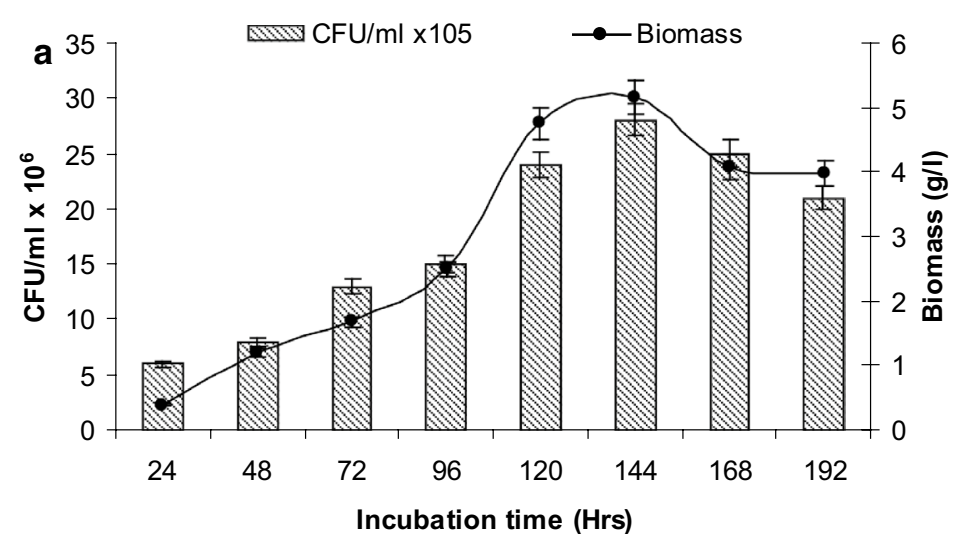

b

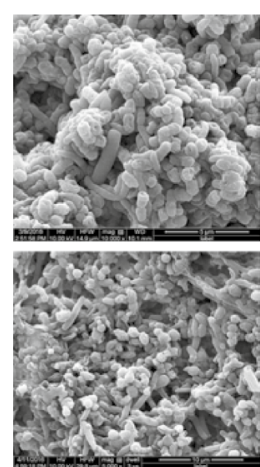

maximum bacterial growth and MRPs decolourisation (74\%). Beside, the SEM analysis of bacterial biomass showed thick biomass under SEM study also supported the high biomass of bacteria.

\section{Enzyme activity}

To observe the function of ligninolytic enzymes in the decolourisation and degradation of SGA-MRPs, enzymes were measured and $\mathrm{MnP}$ was found to be the dominating enzymes at the initial stage of decolourisation. MnP activity was noted maximum at $120 \mathrm{~h}\left(2.8 \mathrm{U} \mathrm{mL}^{-1} \mathrm{~min}^{-1}\right)$, and laccase activity was found maximum $\left(1.91 \mathrm{U} \mathrm{mL}^{-1} \mathrm{~min}^{-1}\right)$ at $144 \mathrm{~h}$ of incubation (Supplementary Fig. S4). But, after 120 and $144 \mathrm{~h}$ incubation showed gradual decrease of $\mathrm{MnP}$ and laccase enzyme activities of bacterial consortium, respectively. The colour reduction of MRPs was significantly initiated at $72 \mathrm{~h}$ and achieve maximum decolourisation at $144 \mathrm{~h}$ incubation.

\section{UV-Vis and FT-IR spectroscopy}

The UV-Vis spectroscopy analysis in range between 200 and $700 \mathrm{~nm}$ for the change of Maillard products was done at 
different time intervals during the optimum decolourisation of SGA-MRPs. The result revealed that Maillard products showed different absorption peaks in the UV region and their maximum absorbance was noted at $250 \mathrm{~nm}$ (Fig. 3a). In addition, MRPs showed different stable peaks in a range of between 200 and $410 \mathrm{~nm}$ (Fig. 3a). The peaks were decreases as the day progresses, which showed the decolourisation of MRPs by bacterial consortium at the end of the $192 \mathrm{~h}$ of incubation.

FT-IR analysis supported the depolymerisation of SGAMRPs after bacterial treatment by shifting the various functional groups as shown in Supplementary Fig. S5. The FT-IR spectrum of the SGA-MRPs is characterized by an intense absorption between 3200 and $3600 \mathrm{~cm}^{-1}$ represented the broad peaks of stretching vibration of $\mathrm{O}-\mathrm{H}$ of $\mathrm{COOH}$ and the $\mathrm{N}-\mathrm{H}$ stretching of amides. The region between 2800 and $3000 \mathrm{~cm}^{-1}$ exhibited the stretching of $\mathrm{C}-\mathrm{H}$ from $-\mathrm{CH}_{3}$ present in hydrocarbons chain. The control sample showed the peaks at 2976.8 , and $2930.3 \mathrm{~cm}^{-1}$ of $\mathrm{C}-\mathrm{H}$ asymmetric stretching vibration of $-\mathrm{CH}$, and $-\mathrm{CH}_{3}$ functional groups. The peak value 2930.3 , and 2946.8 was represented the $\mathrm{C}-\mathrm{H}$ vibrational stretching from $\mathrm{CH}_{3}$ present in hydrocarbon chain. An intense band in the $1500-1750 \mathrm{~cm}^{-1}$ range (1596.0 and 1739.5) may correspond to carbonyl groups in primary amide functions, or it could appear because of the existence of $\mathrm{C}-\mathrm{O}$ stretching of $\mathrm{COO}^{-}$ketonic $\mathrm{C}-\mathrm{O}$ and aromatic $\mathrm{C}-\mathrm{C}$ conjugated with $\mathrm{COO}^{-}$. The absorption band at 1411.1 and $1457.8 \mathrm{~cm}^{-1}$ might appear due to aliphatic $\mathrm{C}-\mathrm{H}$ bending and $\mathrm{COO}^{-}$asymmetric stretching in spectra. The untreated sample showed absorptions peak between 1000 and $1200 \mathrm{~cm}^{-1}$ in untreated and simulated spectra could appear due to $\mathrm{C}-\mathrm{O}$ bonds (ethers and alcohols) and/or minerals. While a band at 922.8 , and $978.0 \mathrm{~cm}^{-1}$ indicated the presence of $\mathrm{C}-\mathrm{O}$ stretching of polysaccharides or $\mathrm{Si}-\mathrm{O}-$ asymmetric stretch. The untreated sample also showed an intense peak at 847.7, 778.5, 629.6 and $535.4 \mathrm{~cm}^{-1}$ represent the sulfate, carbohydrate, alkyl halides, nitro group, and $\mathrm{C}-\mathrm{S}$ bond. The treated sample showed a narrow peak at $3414.0 \mathrm{~cm}^{-1}$ represented the stretching vibration of $\mathrm{O}-\mathrm{H}$ group. The spectra corresponding to treated sample was displays bands at 2855.4 and $2924.8 \mathrm{~cm}^{-1}$, probably due to stretching vibrations of $\mathrm{CH}_{3}$ and $\mathrm{CH}_{2}$ groups, respectively. The broad stretching adsorption band peak at $2160.0 \mathrm{~cm}^{-1}$ could be assigned to $\mathrm{C}=\mathrm{C}$ stretching vibrations. The absorption band at $1444.9 \mathrm{~cm}^{-1}$ might appear due to aliphatic $\mathrm{C}-\mathrm{H}$ bending. The occurrence of aromatic groups is also suggested by absorptions at around $700 \mathrm{~cm}^{-1}$. Moreover, most of the bands were similar between untreated and simulated samples.

\section{HPLC analysis}

The HPLC analysis report demonstrating the area, height, and retention time (RT), before and after bacterial treatment of Maillard products which confirms the degradation of melanoidins (Fig. 3b). The HPLC analysis of untreated samples extracted with ethyl acetate showed a single major peak at RT of $2.40 \mathrm{~min}$, while in $96 \mathrm{~h}$ treated sample was less compared to untreated sample clearly indicates the capability of the bacterial consortium to decolorize and degrade the SGA-MRPs by their enzymatic action. In addition, there

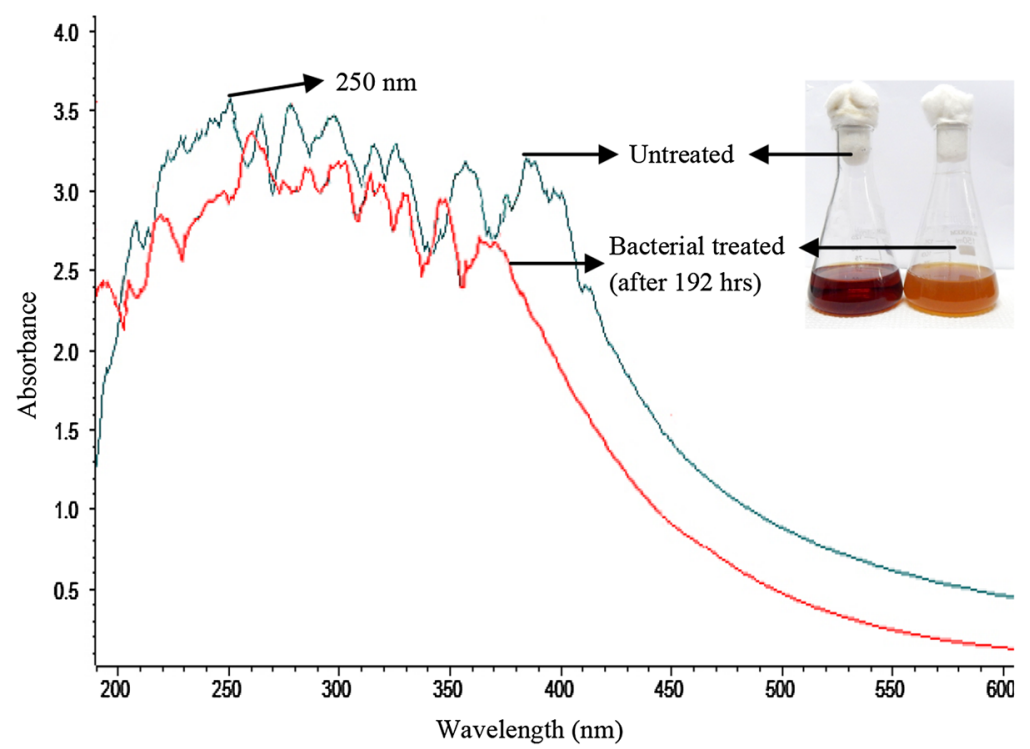

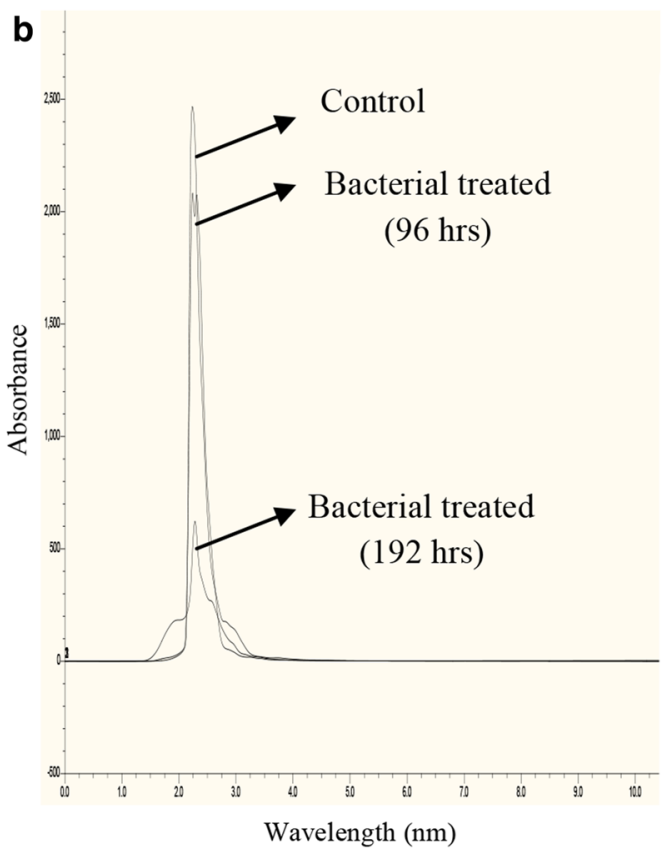

Fig. 3 Analysis of untreated and treated SGA-MRPs at different time interval by a UV-Vis spectrum, and b HPLC analysis (at $250 \mathrm{~nm}$ ) 
were some extra peaks appeared in bacterial treated sample suggesting the formation of several new metabolites. Further, after $192 \mathrm{~h}$ treatment of SGA-MRPs, the HPLC chromatogram also showed shifting of peak, decrease in peak area height, and generation of some new peaks compared to untreated sample. This suggested the biotransformation and biodegradation of SGA-MRPs in various metabolites by developed bacterial consortium.

\section{Identification of organic pollutants and their metabolites}

In the present study, the GC-MS analysis of ethyl acetate extracted untreated SGA-MRPs showed the existence of different types of organic pollutants, most of which were biotransformed and biodegraded during bacterial treatment (Fig. 4; Table 2). The major organic compounds detected in untreated sample at different RT were nonane, 3,7-dimethyl (RT:7.76), 1-octanol,2,2-dimethyl (7.85), dodecane, 2,6, 10-trimethyl (RT:8.05), D-lactic acid-DiTMS (RT:8.34), 1-dodecene (RT:8.41), undecane, 2-methyl (RT:8.80), butanoic acid, TMS ester (RT:9.12), dodecane (RT:9.28), silanol, trimethyl, benzoate (RT:12.36), heptadecane, 2,6,10,15-tetramethyl (RT:13.22), benzeneacetic acid, TMS ester (RT:13.44), 1-tetradecanol (RT:13.60), 2-bromo dodecane (RT:13.93), pentadecane (RT:14.03), dodecane, 2,6,11-trimethyl (RT:14.07), heptadecane (RT:14.47), tetradecane (15.77), hexadecane, 2,6,10,14-tetramethyl (RT:17.60), phenol,2,4-bis (1,1dimethylethyl) (RT:17.95), 1-tetradecanol (RT:18.17), tetradecane, 2,6,10-trimethyl (RT:18.30), hexadecane (RT:19.82), dodecanoic acid, TMS ester (RT:20.77), docosane (RT:21.68), pyrazine, 2,5-dimethyl-3-propyl (RT:21.56), 2,6-diisopropylnaphthalene (RT:22.19), 3,4-tetramethylene-5,5-pentamethyle-2-nepyrazoline (RT:22.66), Hexadecane, 2,6,11,15-tetramethyl (RT:25.64), 7,9-di-tert-butyl-1-oxaspiro(4,5)deca-6,9-diene2,8-dione (RT:25.21), heptacosane (RT:29.40), hexadecanoic acid, TMS ester (RT:27.55), 1H-purin-6-amine,[(2fluorophenyl)]methyl (RT:27.90), pentacosane (RT:29.29), 2,2-bis [(4-trimethylsiloxy)phenyl]propane (RT:30.00), nonacosane (RT:32.30), 1,2-benzenedicarboxylic acid, bis (2-ethylhexyl)ester (RT:33.51), hexadecanoic acid (RT:33.67), octadecane, 3-ethyl-5-(2-ethylbutyl) (RT:33.97), and methylenebis (2,4,6-triisopropylphenylphosphine) (RT:43.94). However, the investigation of bacteria treated SGA-MPs sample has showed the existence of various organic compounds such as, 3-hydroxy-2-butanone, TMS ester (RT:9.41), ethanolamine, TBS (RT:9.65), butane, 2,3-bis (TMSoxy) (RT:10.52), silanol, trimethyl, pentadecane (RT:14.03), undecenoic aicd, TMS ester (RT:18.51), cis-5-dodecanoic acid, TMS ester (RT:22.71), tetradecanoic acid, ethyl ester (RT:24.28), 2-hexadecanol acetate (RT:25.52), trans-9-octadecenoic acid 1TMS (25.60), cis-10-heptadecenoic acid, TMS ester (RT:28.79), octadecanoic acid, ethyl ester (RT:29.72), 11-trans-octadecenoic acid, TMS ester (RT:30.10), methyl 19-methyl-eicosanoate (RT:32.16), 1-docosanol, acetate (RT:33.40), docosanoic acid, methyl ester (34.08), 17-pentatriacontene (RT:35.13), 2-monostearin, TMS ether (RT:35.30), octadecanoic acid, 2,3-bis [(TMS)oxy]propyl ester (RT:35.58), and ethyl tetracosanoate (RT:35.72) at different RT. These compound were completely absent in untreated sample, they are the degraded products of SGA-MRPs and few as new metabolites. In bacterial treated sample two organic compounds i.e. docosane (RT:21.68) and dodecanoic acid, TMS ester (RT:20.77) could not be metabolized.

\section{Effect of SGA-MRPs on seed germination and seedling growth}

The phytotoxicity of untreated and treated sample was assessed by observing the germination percentage and measuring the length of the radical of $P$. mungo L. seeds. It was observed that untreated sample was highly toxic in nature and showed only $75,70,60,15 \%$ germination at 2.5 , 5,10 and $15 \%$ concentration of SGA-MRPs. But, after treatment with bacterial, the toxicity of SGA-MRPs was reduced extensively and showed 90, 90, 80, 25, and 20\% germination at $2.5,5,10,15$, and $20 \%$ concentration of Maillard products (Table 3; Supplementary Fig. S6). The percent germination and radical length were combined for a comprehensive interpretation of Maillard products toxicity in term of GI. The GI of untreated and treated SGA-MRPs values ranged between $0.05-0.61$ and $0.10-0.85$, respectively. The GI was decreased with increased concentration of treated sample compared to untreated sample. The percent phytotoxicity analysis of untreated sample revealed that the phytotoxicity increased with increased in SGA-MRPs concentration but in degraded SGA-MRPs it gradually decreased. Various parameters were studies showed seedling vigor index (16.5-180 and 30-252), stress tolerance index (37.28-81.35 and 50.84-94.91), relative toxicity (85-25 and 80-10) with untreated and treated SGA-MPs, respectively. These results clearly indicated that the toxicity of SGA-MRPs was reduced appreciably after bacterial treatment.

\section{Discussion}

In the present study, bacterial isolates IITRCS01, IITRCS06, IITRCS07, and IITRCS11 showed prominent MnP and laccase activity during the screening on GPM agar plates amended with phenol red and B\&K agar plate amended with guaiacol. The phenol red changed from deep orange to light yellow color during screening of peroxidase activity in bacteria has been used as an indicator of MnP activity shown 

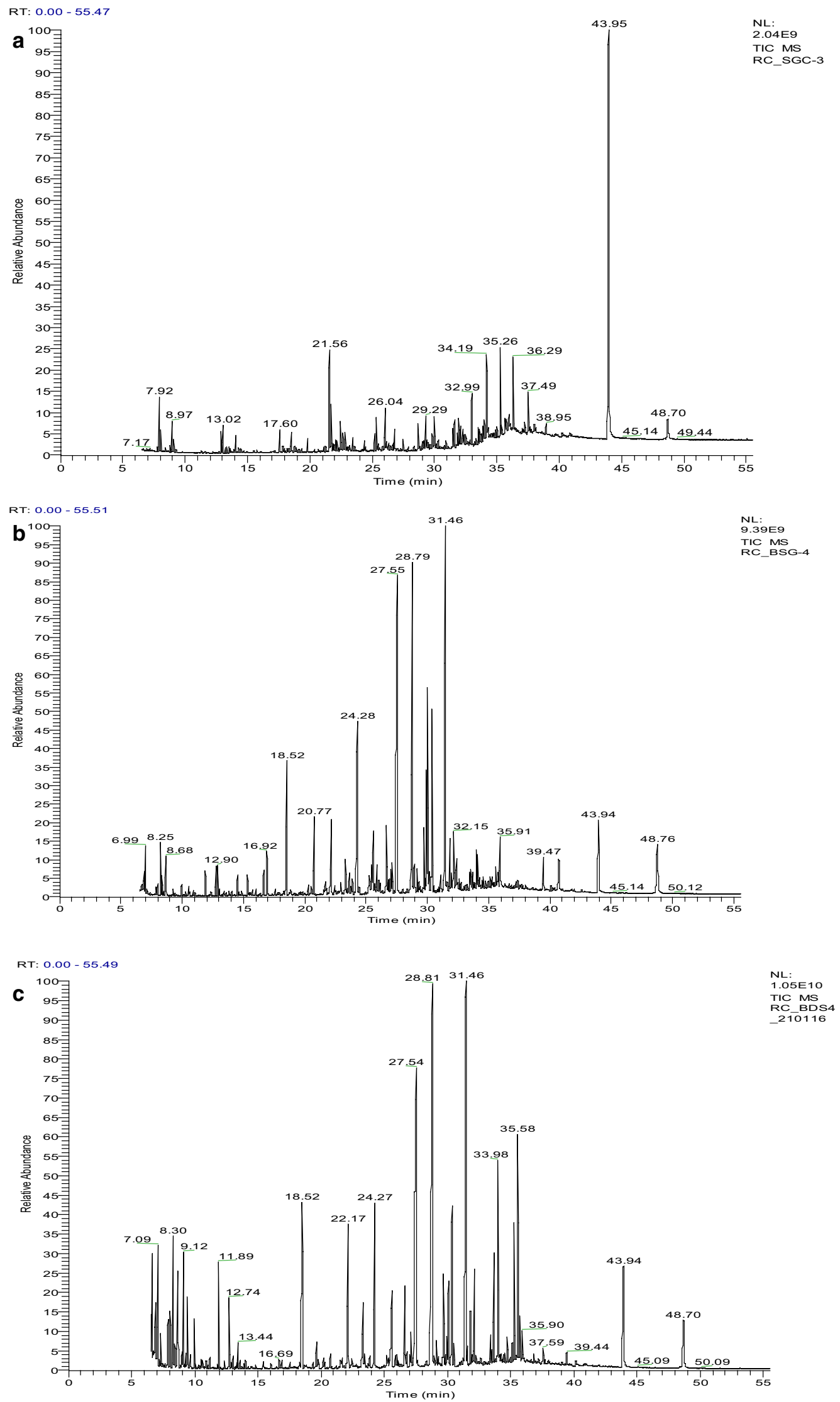
४Fig. 4 GC-MS chromatogram of organic compounds extracted with ethyl acetate from SGA-MRPs. a Control, b bacterial degraded after $96 \mathrm{~h}$ incubation, and $\mathbf{c}$ bacterial degraded after $192 \mathrm{~h}$ incubation

in Supplementary Fig. S4. This change in colour of phenol red occurred due to oxidation of glucose by sugar oxidase enzyme, resulting in the production of $\mathrm{H}_{2} \mathrm{O}_{2}$ and media acidification (i.e. lowering of $\mathrm{pH}$ ) which is required for the melanoidins degradation (Aoshima et al. 1985; Hwang et al. 2011). The guaiacol is also a chromogenic substrate that is used for quick screening of microbial strains producing laccases by means of a color reaction (Okino et al. 2000). The selected four bacterial strains produced the laccase which catalyzed the oxidation of guaiacol to form reddish brown halo zones in the medium (Supplementary Fig. S4). This observation corroborated with earlier finding for screening of $\mathrm{MnP}$ and laccase producing bacterial strains by Chandra and Singh (2012). The 16S rRNA genes sequence analysis showed that screened bacterial strain IITRCS01, IITRCS06, IITRCS07, and IITRCS11 were identified as K. pneumoniae (KU726953), S. enterica (KU726954), E. aerogenes (KU726955), E. cloaceae (KU726957), respectively. This bacterial species belonged to group Gammaproteobacteria. The class Gammaproteobacteria constitutes a very large and diverse group of bacteria that exhibits enormous variety in terms of their phenotype and metabolic capabilities (Woese et al. 1985; Brenner et al. 2005; Kersters et al. 2006). Members of this group exhibit broad ranges of aerobicity, of trophism, including chemoautotrophism and photoautotrophism, and of temperature adaptation. The class Gammaproteobacteria also includes enteric bacteria and it is well known for harbouring large numbers of human, animal and plant pathogens (Brenner et al. 2005; Kersters et al. 2006). Although, Gammaproteobacteria has only the taxonomic rank of class within the phylum Proteobacteria.

Since, MR is a complex series of chemical reaction that occurs between the carbonyl groups of reducing sugars and the amino groups of amino acids, peptides or proteins (Echavarría et al. 2013a, b). The MRPs are a particularly complex mixture of various organic compounds of different molecular weights. They include not only aldehydes, ketones, dicarbonyls, acryl amides, and heterocyclic amines, but also melanoidins, which are polymeric products formed at the advanced steps of MR (Wang et al. 2011). In this study, we have selected sucrose, glutamic acid, and sodium carbonate for the synthesis of MRPs due to presence of sucrose and glutamic acid abundantly present in sugarcane juice, which are highly reactive in the MR at elevated temperature, sucrose invariably hydrolyses first to the reducing thermolabile hexose sugar, glucose and fructose, which enter into the initiation pathway of MR (Walford 1996; Nolasco Junior and De Massaguer 2006). The alkaline $\mathrm{pH}$ (8.0) favour the MR, because at alkaline $\mathrm{pH}$ sugar thermal degradation rate increased which leads formation of colour. Therefore, color formation under alkaline condition is result of sucrose degradation into reducing sugar at initial stage (Eggleston and Vercellotti 2000). In addition, the used of sodium carbonate also favour the reaction of MRPs formation during the decomposition of sugar. Further, the physico-chemical characteristics of untreated MRPs showed dark brown in color at high BOD, COD, TDS, VS, and phenolics at $\mathrm{pH}$ 6.9. Thus, the high BOD and COD values of the MRPs solution are due to lack of oxygen molecule in MRPs during the synthesis of MRPs after dehydration process. Since, some caramelized sugar may be also generated during the MRPs synthesis. Therefore, high TDS of solution is found in this study. However, in contrary to control, the bacterial degraded sample showed reduction of BOD, COD, TDS, VS and phenolics values. This indicated the degradation of MRPs by inoculated bacterial consortium due to presence of ligninolytic enzyme activities. Consequently, the reduction in colour was noted due to depolymerisation of melanoidins as reported earlier (Verman et al. 1974). At the initial stage of bacterial incubation during the decolourisation process the $\mathrm{pH}$ of medium was noted 4.1. This might be due to generation of some organic acids with bacterial reaction in medium composition (Davídek et al. 2006). But, it gradually moves towards alkaline condition ( $\mathrm{pH} \mathrm{8.1)}$ after $192 \mathrm{~h}$ of bacterial incubation. The increased $\mathrm{pH}$ of media might be due to depolymerisation of MRPs by enzyme activity of bacterial consortium. This induced the solubility and utilisation of melanoidins which favoured the mineralisation and co-metabolism of MRPs (Bharagava et al. 2009). These results also corroborated to the previous findings regarding the degradation of natural and synthetic melanoidins (Bharagava et al. 2009; Kumar and Chandra 2006; Yadav and Chandra 2012).

A potential consortium was developed from selected strains of bacteria for decolourisation of MRPs. It has been reported glucose is an essential carbon source for melanoidins decolourisation (Kumar and Chandra 2006). In our investigation, the potential bacterial consortium showed maximum decolourisation $(65.8 \%)$ at $1.0 \%$ concentration of glucose. While in absence of glucose the slow growth of bacterial consortium was noted. This revealed that the carbon source present in MRPs is not readily being utilised by bacterial consortium. But, the supplementation of glucose in media was readily available for bacterial growth. This indicated strong evidence that incubated bacterial consortium is not able to utilise the SGA-MRPs for its growth and metabolism. Similar observation has also been reported by previous worker in case of anaerobically treated distillery spent wash (Ghosh et al. 2004). This indicated that our bacterial consortium was more effective for decolourisation and degradation of MRPs. This might be due to induction of hight amount of ligninolytic enzyme which facilitated 
Table 2 Organic compounds identified by GC-MS analysis extracted with ethyl acetate from untreated (control) and bacterial treated SGA-MRPs

\begin{tabular}{|c|c|c|c|c|c|}
\hline \multirow[t]{2}{*}{ SI. No. } & \multirow[t]{2}{*}{ Name of compound } & \multirow[t]{2}{*}{ RT } & \multirow[t]{2}{*}{$\mathrm{C}$} & \multicolumn{2}{|l|}{$\mathrm{BT}$} \\
\hline & & & & $96 \mathrm{~h}$ & $192 \mathrm{~h}$ \\
\hline 1 & Nonane, 3,7-dimethyl & 7.76 & + & - & - \\
\hline 2 & Butane, 2,3-bis(trimethylsiloxy) & 7.82 & - & + & - \\
\hline 3 & 1-Octanol,2,2-dimethyl & 7.85 & + & - & - \\
\hline 4 & 3,6-Dioxa-2,7-disilaoctane, 2,2,4,5,7,7-hexamethyl & 8.00 & - & + & - \\
\hline 5 & Dodecane, 2,6, 10-trimethyl & 8.05 & + & - & - \\
\hline 6 & D-Lactic acid-DiTMS & 8.34 & + & - & - \\
\hline 7 & 1-Dodecene & 8.41 & + & - & - \\
\hline 8 & Piperidine, 1,4-dimethyl & 8.68 & - & + & - \\
\hline 9 & Undecane, 2-methyl & 8.80 & + & - & - \\
\hline 10 & Butanoic acid, TMS ester & 9.12 & + & - & - \\
\hline 11 & Dodecane & 9.28 & + & + & - \\
\hline 12 & 3-Hydroxy-2-butanone. TMS ester & 9.41 & - & - & + \\
\hline 13 & Ethanolamine, TBS & 9.65 & - & - & + \\
\hline 14 & Silane, trimethyl(4-methylphenoxy) & 10.31 & - & + & - \\
\hline 15 & Butane, 2,3-bis(TMSoxy) & 10.52 & - & - & + \\
\hline 16 & $\alpha$-D-Mannopyranoside, methyl, cyclic 2,3:4,6-bis(butyloboronate) & 10.53 & - & + & - \\
\hline 17 & 2-Hexenoic acid, 5-(1-ethoxyethoxy), 2-(TMS)ethyl ester & 10.57 & - & + & - \\
\hline 18 & Silanol, trimethyl, benzoate & 12.36 & + & - & - \\
\hline 19 & Octanoic acid, TMS ester & 12.75 & - & + & - \\
\hline 20 & Silanol, trimethyl-phosphate & 12.90 & + & - & - \\
\hline 21 & Heptadecane, 2,6,10,15-tetramethyl & 13.22 & + & - & - \\
\hline 22 & Benzeneacetic acid, TMS ester & 13.44 & + & - & - \\
\hline 23 & 1-Tetradecanol & 13.60 & + & - & - \\
\hline 24 & Butanedioic acid, bis(TMS)ester & 13.82 & - & + & - \\
\hline 25 & 2-Bromo dodecane & 13.93 & + & - & - \\
\hline 26 & Pentadecane & 14.03 & + & - & + \\
\hline 27 & Dodecane, 2,6,11-trimethyl & 14.07 & + & - & - \\
\hline 28 & Vanillin, tert-butyldimethylsilyl ether & 14.45 & - & + & - \\
\hline 29 & Heptadecane & 14.47 & + & - & - \\
\hline 30 & 4-Methoxy- $\alpha$-(TMS)benzenemethanol & 14.51 & - & + & - \\
\hline 31 & Nonanoic acid, TMS ester & 14.85 & - & + & - \\
\hline 32 & 1H-Purine-2,6-dione, 3,7-dihydro-1,3-dimethyl-7-(TMS) & 15.34 & - & + & - \\
\hline 33 & Tetradecane & 15.77 & + & - & - \\
\hline 34 & Decanoic acid, TMS ester & 16.92 & - & + & - \\
\hline 35 & Hexadecane, 2,6,10,14-tetramethyl & 17.60 & + & - & - \\
\hline 36 & 2-(2-(2-Butoxyethoxy)ethoxy)ethoxy-trimethylsilane & 17.84 & + & - & - \\
\hline 37 & Phenol,2,4-bis(1,1dimethylethyl) & 17.95 & + & - & - \\
\hline 38 & 1-Tetradecanol & 18.17 & + & - & - \\
\hline 39 & Tetradecane, 2,6,10-trimethyl & 18.30 & + & - & - \\
\hline 40 & Undecenoic aicd, TMS ester & 18.51 & - & - & + \\
\hline 41 & Undecenoic acid, TMS ester & 18.52 & - & + & - \\
\hline 42 & Hexadecane & 19.82 & + & - & - \\
\hline 43 & Dodecanoic acid, TMS ester & 20.77 & + & + & + \\
\hline 44 & Pumiliotoxin & 20.52 & - & + & - \\
\hline 45 & Docosane & 21.68 & + & + & + \\
\hline 46 & Pyrazine, 2,5-dimethyl-3-propyl & 21.56 & + & - & - \\
\hline 47 & Glucopyranose-1,2,3,5-Di-methylboronate-TMS & 22.11 & - & + & - \\
\hline 48 & 2,6-Diisopropylnaphthalene & 22.19 & + & - & - \\
\hline 49 & 3,4-Tetramethylene-5,5-pentamethyle-2-nepyrazoline & 22.66 & + & - & - \\
\hline 50 & Cis-5-Dodecanoic acid, TMS ester & 22.71 & - & + & + \\
\hline 51 & Leucine & 22.82 & + & - & - \\
\hline
\end{tabular}


Table 2 (continued)

\begin{tabular}{|c|c|c|c|c|c|}
\hline \multirow[t]{2}{*}{ SI. No. } & \multirow[t]{2}{*}{ Name of compound } & \multirow[t]{2}{*}{ RT } & \multirow[t]{2}{*}{$\mathrm{C}$} & \multicolumn{2}{|l|}{ BT } \\
\hline & & & & $96 \mathrm{~h}$ & $192 \mathrm{~h}$ \\
\hline 52 & Tetradecanoic acid, ethyl ester & 23.32 & - & + & - \\
\hline 53 & Myristoleic acid ITMS & 23.87 & - & + & - \\
\hline 54 & Tetradecanoic acid, TMS ester & 24.20 & - & + & - \\
\hline 55 & Tetradecanoic acid, ethyl ester & 24.28 & - & - & + \\
\hline 56 & Hexadecane, 2,6,11,15-tetramethyl & 25.34 & + & - & - \\
\hline 57 & 7,9-Di-tert-butyl-1-oxaspiro(4,5)deca-6,9-diene-2,8-dione & 25.21 & + & - & - \\
\hline 58 & n-Pentadecanoic acid, TMS ester & 25.43 & - & + & \\
\hline 59 & 2-Hexadecanol acetate & 25.52 & - & - & + \\
\hline 60 & 1,4-Diaza-2,5-dioxa-3-isobutyl bicycle nonane & 25.60 & - & + & - \\
\hline 61 & Trans-9-Octadecenoic acid 1TMS & 25.60 & - & - & + \\
\hline 62 & Heptacosane & 29.40 & + & - & - \\
\hline 63 & Hexadecanoic acid, TMS ester & 27.55 & + & + & + \\
\hline 64 & 1H-Purin-6-amine,[(2-fluorophenyl)]methyl & 27.90 & + & - & - \\
\hline 65 & Cis-9-Hexadecenoic acid, TMS ester & 27.14 & - & + & - \\
\hline 66 & Cis-10-Heptadecenoic acid, TMS ester & 28.79 & - & + & + \\
\hline 67 & Pentacosane & 29.29 & + & - & - \\
\hline 68 & Octadecanoic acid, ethyl ester & 29.72 & - & + & + \\
\hline 69 & 9,12-Octadecadienoic acid, TMS ester & 29.93 & - & + & - \\
\hline 70 & 2,2-Bis[(4-trimethylsiloxy)phenyl]propane & 30.00 & + & - & - \\
\hline 71 & 11-Trans-Octadecenoic acid, TMS ester & 30.10 & - & + & + \\
\hline 72 & Octadecanoic acid, TMS ester & 30.38 & - & + & - \\
\hline 73 & Cis-10-Nonadecenoic acid, TMS ester & 31.46 & - & + & + \\
\hline 74 & Methyl 19-methyl-eicosanoate & 32.16 & - & + & + \\
\hline 75 & Nonacosane & 32.30 & + & - & - \\
\hline 76 & 2-Acetyl-3-(2-cinnamido)ethyl-7-methoxyindole & 32.38 & - & + & - \\
\hline 77 & 17-Pentatriacontane & 33.41 & - & + & - \\
\hline 78 & 1,2-Benzenedicarboxylic acid, bis(2-ethylhexyl)ester & 33.51 & + & - & - \\
\hline 79 & 1-Docosanol, acetate & 33.40 & - & - & + \\
\hline 80 & Hexadecanoic acid & 33.67 & + & - & - \\
\hline 81 & Dotriacontane & 33.90 & - & + & - \\
\hline 82 & Octadecane, 3-ethyl-5-(2-ethylbutyl) & 33.97 & + & - & - \\
\hline 83 & Hexadecanoic acid, 2,3-bis[(TMS)oxy]propyl ester & 33.98 & - & - & + \\
\hline 84 & Hexadecanoic acid, 2,3-bis[(TMS)oxy]propyl ester & 33.99 & - & + & - \\
\hline 85 & Docosanoic acid, methyl ester & 34.08 & - & - & + \\
\hline 86 & Ethyl docosanoate & 34.09 & - & + & - \\
\hline 87 & Cis-13-docodenoic acid, TMS ester & 34.24 & - & + & - \\
\hline 88 & Docosanoic acid, TMS ester & 34.45 & - & + & - \\
\hline 89 & Quercetin $7,3^{\prime}, 4^{\prime}$, -trimethoxy & 34.72 & - & + & - \\
\hline 90 & Heptacosane & 34.99 & - & + & - \\
\hline 91 & 17-Pentatriacontene & 35.13 & - & - & + \\
\hline 92 & 2-Monostearin, TMS ether & 35.30 & - & + & + \\
\hline 93 & Octadecanoic acid, 2,3-bis[(TMS)oxy]propyl ester & 35.58 & - & - & + \\
\hline 94 & Ethyl tetacosanoate & 35.72 & - & - & + \\
\hline 95 & 2,6,10,14,18,22-Tetracohexane, 2,6,10,15,19,23-hexamethyl & 35.91 & - & + & - \\
\hline 96 & Silane, $[[(3 \beta)$-cholest-5-en-3-yl]oxy]TM & 39.47 & - & + & - \\
\hline 97 & Silane, (ergosta-5,7,22-trien-3 $\beta$-yl)TM & 40.71 & - & + & - \\
\hline 98 & Methylenebis (2,4,6-triisopropylphenylphosphine) & 43.94 & + & - & - \\
\hline
\end{tabular}

$T M S$ trimethylsilyl, $C$ control, $B T$ bacterial treated, $R T$ retention time 
Table 3 Effect of untreated and bacterial treated SGA-MRPs on the seed germination and seedling growth of Phaseolus mungo L

\begin{tabular}{|c|c|c|c|c|c|c|c|c|}
\hline Samples & Treatment $(\%)$ & $\begin{array}{l}\text { Germination } \\
(\%)\end{array}$ & $\begin{array}{l}\text { Germination } \\
\text { index }\end{array}$ & $\begin{array}{l}\text { Phytotoxicity } \\
(\%)\end{array}$ & $\begin{array}{l}\text { Seedling vigor } \\
\text { index }\end{array}$ & $\begin{array}{l}\text { Stress toler- } \\
\text { ance index } \\
(\%)\end{array}$ & $\begin{array}{l}\text { Relative toxic- } \\
\text { ity }(\%)\end{array}$ & $\begin{array}{l}\text { Radical length } \\
(\mathrm{cm})\end{array}$ \\
\hline \multirow[t]{5}{*}{ Untreated } & 2.5 & $75 \pm 0.00$ & $0.61 \pm 0.00$ & $18.64 \pm 0.09$ & $180 \pm 8.01$ & $81.35 \pm 0.02$ & $25 \pm 0.01$ & $2.40 \pm 0.01$ \\
\hline & 5 & $70 \pm 0.00$ & $0.48 \pm 0.00$ & $30.50 \pm 0.06$ & $143.50 \pm 4.21$ & $69.49 \pm 0.02$ & $30 \pm 0.03$ & $2.05 \pm 0.01$ \\
\hline & 10 & $60 \pm 0.00$ & $0.30 \pm 0.00$ & $49.15 \pm 0.07$ & $90 \pm 0.08$ & $50.84 \pm 0.01$ & $40 \pm 0.02$ & $1.50 \pm 0.00$ \\
\hline & 15 & $15 \pm 0.00$ & $0.05 \pm 0.00$ & $62.71 \pm 0.04$ & $16.5 \pm 0.01$ & $37.28 \pm 0.01$ & $85 \pm 0.11$ & $1.10 \pm 0.00$ \\
\hline & 20 & NG & - & - & - & - & - & - \\
\hline \multirow[t]{5}{*}{ Treated } & 2.5 & $90 \pm 0.00$ & $0.85 \pm 0.00$ & $5.08 \pm 0.01$ & $252 \pm 14.01$ & $94.91 \pm 0.03$ & $10 \pm 0.00$ & $2.80 \pm 0.01$ \\
\hline & 5 & $90 \pm 0.00$ & $0.71 \pm 0.00$ & $20.33 \pm 0.01$ & $211.5 \pm 9.14$ & $79.66 \pm 0.02$ & $10 \pm 0.00$ & $2.35 \pm 0.01$ \\
\hline & 10 & $80 \pm 0.00$ & $0.61 \pm 0.00$ & $23.05 \pm 0.03$ & $181.6 \pm 4.21$ & $76.94 \pm 0.02$ & $20 \pm 0.01$ & $2.27 \pm 0.02$ \\
\hline & 15 & $25 \pm 0.00$ & $0.18 \pm 0.00$ & $27.11 \pm 0.02$ & $53.75 \pm 0.04$ & $72.88 \pm 0.01$ & $75 \pm 0.09$ & $2.15 \pm 0.01$ \\
\hline & 20 & $20 \pm 0.00$ & $0.10 \pm 0.00$ & $49.15 \pm 0.01$ & $30 \pm 0.00$ & $50.84 \pm 0.01$ & $80 \pm 0.17$ & $1.50 \pm 0.00$ \\
\hline Control & 0 & $100 \pm 0.00$ & - & - & $295 \pm 24.01$ & - & - & $2.95 \pm 0.01$ \\
\hline
\end{tabular}

All values are mean of three replicates $\pm \mathrm{SD}$

$N G$ no germination, control tap water

for the decolourisation processes (Kumar and Chandra 2006). Simultaneously, the effect of various concentration of organic (peptone, beef extract, yeast extract, and urea) and inorganic nitrogen (sodium sulphate and ammonium chloride) sources on MRPs decolourisation was investigated, but peptone was found most effective organic nitrogen source which showed decolourisation upto $72 \%$ at $0.1 \%$ (w/v) concentration. Because, peptone are rich in free amino acids and short peptides, which support cell growth with a low consumption rate of the carbon source and minimize the accumulation of by-products (Lau et al. 2004). Moreover, presence of other sources of organic nitrogen could show the decolorization upto 55-58\% only, whereas inorganic nitrogen could show the decolourisation upto 15-32\%. Thus, this finding showed the inhibitory effect of sodium sulphate and ammonium chloride on bacterial growth. Similar, effect has also been reported by previous workers for melanoidins decolourisation (Tiwari et al. 2012, 2013; Yadav and Chandra 2012; Sirianuntapiboon et al. 2004). Hence, the developed bacterial consortium utilised tiny amount of peptone for higher decolourisation, BOD, and COD reduction compared to other researchers ever reported.

The variation in SGA-MRPs decolourisation process was directly affected with change in $\mathrm{pH}$ and temperature of culture conditions. The optimum SGA-MRPs decolourisation (72\%) was noted at $\mathrm{pH} 8.1$ by developed bacterial consortium after $192 \mathrm{~h}$ of incubation. Further, increase or decrease in $\mathrm{pH}$ inhibited the decolourisation process. This might be due to inhibition of the enzyme activity. For developed aerobic bacterial consortium comprising Bacillus sp., Bacillus licheniformis, and Alcaligenes sp. was showed highest decolourisation activity at pH 7.0 (Bharagava and Chandra 2010). In another study, the optimum $\mathrm{pH}$ for melanoidins decolourisation by bacterial strains Alcaligenes faecalis $\mathrm{SAG}_{5}$ was note at pH 7.5 (Santal et al. 2011). The developed bacterial consortium showed maximum decolourisation (70\%) at $37^{\circ} \mathrm{C}$. While further, increase in temperature up to $45^{\circ} \mathrm{C}$ adversely affected the growth, metabolism and MRPs decolourisation ability of bacterial consortium. Similar pattern is also reported in other studies also (Mohana et al. 2007; Santal et al. 2011). However, the Maillard products were significantly affected by various shaking speed also. It was observed that the optimum decolourisation (70\%) by potential bacterial consortium was noted at $180 \mathrm{rpm}$. However, increase in shaking speed resulted decrease in decolourisation process. This might be due to mechanical injury of bacterial cell wall at a higher shaking speed (Tiwari et al. 2014; Yadav and Chandra 2012).

For efficient and potential consortium, different inoculums ratio of bacterial strains were also optimized. Consortium having 1:1:1:1 inoculums ratio of bacteria showed maximum (74\%) decolourisation of MRPs within biomass $\left(5.15 \mathrm{~g} \mathrm{~L}^{-1}\right.$; CFU mL $\left.{ }^{-1} 28 \times 10^{6}\right) \mathrm{OD}_{620}(2.49)$ at $144 \mathrm{~h}$ of incubation. Further, incubation did not increase the rate of decolourisation. The direct correlation of $\mathrm{OD}_{620}$ with high bacterial biomass indicated the direct involvement in decolourisation and degradation process of MRPs. This indicted high bacterial growth was due to utilisation of MRPs as a carbon source for its growth.

During the maximum decolourisation of MRPs, the MnP activity was noted highest $\left(2.8 \mathrm{U} \mathrm{mL}^{-1} \mathrm{~min}^{-1}\right)$ at $120 \mathrm{~h}$ of incubation and laccase activity was found highest (1.91 $\mathrm{U} \mathrm{mL}{ }^{-1} \mathrm{~min}^{-1}$ ) at $144 \mathrm{~h}$ of incubation. The MnP and laccase have a broad substrate oxidising enzymes reported for detoxification and degradation of phenolic and non-phenolic polymeric compounds (Rodriguez et al. 1999; González 
et al. 2008). The presence of melanoidins and other similar compounds can induce the expression of MnP and laccase protein both are having synergistic action in the degradation and depolymerisation of melanoidins and other industrial pollutants (Miyata et al. 2000; González et al. 2008). In our study, MnP was profusely present at the initial phase of bacterial growth, while laccase was produced in later phase of growth during MRPs degradation. The findings of this study are well supported by earlier results reported by various workers (Pant and Adholeya 2007, 2009b; Yadav and Chandra 2012).

$\mathrm{UV}-\mathrm{Vis}$ spectrophotometric analysis is the most common used method of the MR (Martins and Van Boekel 2003; Echavarría et al. 2014). In this study, MRPs showed different absorption peaks in a range of between 200 and $410 \mathrm{~nm}$ and their maximum absorbance was noted at $250 \mathrm{~nm}$ (Fig. 3a). The stable peaks absorbance in UV region indicated the presence of several organic compounds formed during the early stages of the MR (Echavarría et al. 2013a, b). While, the absorbance of either $280 \mathrm{~nm}, 320-350 \mathrm{~nm}$ or 420-450 nm corresponding to early MRPs for pyrazine compounds (at $280 \mathrm{~nm}$ ) (Gu et al. 2010), advanced stage for soluble pre-melanoidins formation (at 320-350 nm) and final MRPs (at 420-450 nm) corresponding to polymerised MRPs in medium (Billaud et al. 2004). On the basis of our findings, it can be stated that the formation of various peaks in UV and visible region indicated the presence of complex mixture of early, advanced and final MRPs. Our findings corroborated with the earlier results reported by Echavarría et al. (2013a, b).

The FT-IR spectrum of the SGA-MRPs is characterized by an intense absorption between 3200 and $3600 \mathrm{~cm}^{-1}$ represented the broad peaks of stretching vibration of $\mathrm{OH}$ of $\mathrm{COOH}$ and $\mathrm{N}-\mathrm{H}$ of amides. The peak value 3519.4, 3486.2 , 3427.6, 3397.9, 3366.1, and $3333.1 \mathrm{~cm}^{-1}$ was represented the $\mathrm{O}-\mathrm{H}$ vibrational stretching present in acids, alcohol and phenol (Ramezani et al. 2011). The region between 2800 and $3000 \mathrm{~cm}^{-1}$ exhibited the stretching of C-H from $-\mathrm{CH}_{3}$ present in hydrocarbons chain (Kadam et al. 2013). The weakening of $\mathrm{O}-\mathrm{H}$ group was probably due to action of bacterial enzyme which cleaved the $\mathrm{C}-\mathrm{O}$ bond and eventually removed the $\mathrm{O}-\mathrm{H}$ group from the polymer. These results are corroborated by previous findings (Liakos and Lazaridis 2014; Ramezani et al. 2011). The additional peaks in the treated effluent are due to degradation of SGA-MPs by developed bacterial consortium. In HPLC analysis, the SGA-MRPs showed major peak at $2.40 \mathrm{~min}$ but after bacterial treatment the height and area of peak reduced and some additional peaks was also observed. This indicated the biotransformation of Maillard products and formation of some new metabolites. These findings are well supported by earlier results reported by various researchers (Tiwari et al. 2012; Yadav and Chandra 2012).

GC-MS is an ideal technique for the determination of organic pollutants in environment. The major organic compounds detected in untreated sample were organic acids, pyrazine and phenolic compounds. Lactic acid, benzeneacetic acid, and benzenedicarboxylic acid are the alkaline degradation products of hexose. Pyrazines are the amadori products play a key role during the Maillard product synthesis. Phenolic compounds are the fragmentary product of amadori compound. The presence of organic acids, phenolics and long chain aliphatic compounds in wastewater was reported previously by various workers (Gonzalez et al. 2000; Chandra and Kumar 2017). However, the analysis of sample after bacteria treatment has showed the presence of various organic compounds as shown in Table 2. Similar, compounds have been identified in distillery effluent after treatment with Emericella nidulans var. lata, $N$. intermedia followed by Bacillus sp. in three stage bioreactor (Kaushik et al. 2010). However, several organic compounds detected in untreated sample were diminished after bacterial treatment. This suggested that complex and high molecular weight compounds were degraded by bacterial consortium with the help of extracellular ligninolytic enzymes. These organic compounds were utilized as sole carbon, nitrogen and energy source and played a key role in the decolourisation and degradation of SGA-MRPs.

The toxicity study of degraded and undegraded SGAMRPs with $P$. mungo L. seeds showed that untreated sample was highly toxic in nature and showed only $75,70,60$, $15 \%$ germination at different concentration of SGA-MRPs. While, the toxicity of degraded SGA-MRPs sample was significantly reduced. Suppression of germination at high concentration of SGA-MRPs might be due to the occurrence of highly toxic organic pollutants and dissolve solid which absorbed by the seed before germination and affecting different biochemical and physiological process of seed germination (Bharagava and Chandra 2010). Increased in percent germination in treated SGA-MRPs might be due to decrease of organic compounds that has created favorable environment for germination and utilisation of nutrient present in Maillard products.

\section{Conclusion}

This study has revealed that SGA-MRPs showed mixture of variable molecular weight melanoidins. Therefore, several peaks were noted in rage of $200-450 \mathrm{~nm}$. Further, this study also showed that the developed bacterial consortium has ability to degrade and decolourise recalcitrant complex SGA-MRPs polymer up to $70 \%$ in existence of adequate 
carbon and nitrogen source at broad range of temperature, $\mathrm{pH}$, and shaking speed within a incubation period of $192 \mathrm{~h}$. GC-MS and other spectrophotometric analysis of untreated and bacterial treated sample of SGA-MRPs have shown that the majority of the colours containing compounds (melanoidins) detected in untreated sample were diminished from the treated sample by MnP and laccase enzyme activity of bacteria. Hence, the optimized conditions for developed bacterial consortium can be used for decolourisation of MRPs containing industrial wastewater at large scale.

Acknowledgements Instrumentation facilities for scanning electron microscopy from central facilities, CSIR-IITR, Lucknow, Uttar Pradesh, India are gratefully acknowledged. The financial assistance from DBT, New Delhi, India to Prof. Ram Chandra and Rajiv Gandhi National Senior Research Fellowship (RGNSRF) from University Grant Commission, New Delhi, to Mr. Vineet Kumar, Ph.D. Scholar is highly acknowledged.

Open Access This article is distributed under the terms of the Creative Commons Attribution 4.0 International License (http://creativeco mmons.org/licenses/by/4.0/), which permits unrestricted use, distribution, and reproduction in any medium, provided you give appropriate credit to the original author(s) and the source, provide a link to the Creative Commons license, and indicate if changes were made.

\section{References}

AIDA (All India Distillers' Associations) (2016) Annual report. New Delhi, http://www.aidaindia.org/annual-report.html

Aoshima I, Tozawa Y, Ohmomo S, Ueda K (1985) Production of decolorizing activity for molasses pigment by Coriolus versicolor Ps4a. Agric Biol Chem 49:2041-2045

APHA (American Public Health Association) (2012) Standard method for examination of water and wastewater, 22nd edn. APHA, AWWA, WEF, Washigton, DC

Arimi MM, Zhang Y, Götz G, Kiriamiti K, Geißen SU (2014) Antimicrobial colorants in molasses distillery wastewater and their removal technologies. Int Biodeterior Biodegrad 87:34-43

Arora DS, Chander M, Gill PK (2002) Involvement of lignin peroxidase, manganese peroxidase and laccase in degradation and selective ligninolysis of wheat straw. Int Biodeterior Biodegrad 50:115-120

Barrow GI, Feltham RKA (2003) Cowan and Steels, Manual for the identification of medical bacteria, 3rd edn. Cambridge University Press, Cambridge

Bharagava RN, Chandra R (2009) Isolation and characterisation of phenolic compounds by $1 \mathrm{H}$ NMR and mass spectrometric analysis from sugarcane molasses post methanated distillery effluent. Indian J Environ Prot 29:873-888

Bharagava RN, Chandra R (2010) Biodegradation of the major color containing compounds in distillery wastewater by an aerobic bacterial culture and characterization of their metabolites. Biodegradation 21:703-711

Bharagava RN, Chandra R, Rai V (2009) Isolation and characterization of aerobic bacteria capable of the degradation of synthetic and natural melanoidins from distillery effluent. World J Microbiol Biotechnol 25(5):737-744

Billaud C, Maraschin C, Nicolas J (2004) Inhibition of polyphenoloxidase from apple by Maillard reaction products prepared from glucose or fructose with L-cysteine under various conditions of $\mathrm{pH}$ and temperature. LWT 37:69-78

Brenner DJ, Krieg NR, Staley JT, Garrity GM (2005) Bergey's manual of systematic bacteriology. Springer, New York

Chandra R, Kumar V (2017) Detection of Bacillus and Stenotrophomonas species growing in an organic acid and endocrine-disrupting chemicals rich environment of distillery spent wash and its phytotoxicity. Environ Monit Assess 189:26

Chandra R, Singh H (1999) Chemical decolourisation of anaerobically treated distillery effluent. Indian J Environ Prot 19(11):833-837

Chandra R, Singh R (2012) Decolourisation and detoxification of rayon grade pulp paper mill effluent by mixed bacterial culture isolated from pulp paper mill effluent polluted site. Biochem Eng J 61:49-58

Chandra R, Bharagava RN, Rai V (2008a) Melanoidins as major colourant in sugarcane molasses based distillery effluent and its degradation. Bioresour Technol 99:4648-4660

Chandra R, Yadav S, Mohan D (2008b) Effect of distillery sludge on seed germination and growth parameters of green gram (Phaseolus mungo L.). J Hazard Mater 152:431-439

Chandra R, Bharagava RN, Rai V, Singh SK (2009) Characterization of sucrose-glutamic acid Maillard products (SGMPs) degrading bacteria and their metabolites. Bioresour Technol 100:6665-6668

D'Souza DT, Tiwari R, Sah AK, Raghukumar C (2006) Enhanced production of laccase by a marine fungus during treatment of colored effluents and synthetic dyes. Enzyme Microb Technol 38:504-511

David Noel S, Rajan MR (2015) Phytotoxic effect of dyeing industry effluent on seed germination and early growth of lady's finger. J Pollut Eff Control 3:138

Davídek T, Devaud S, Robert F, Blank I (2006) Sugar fragmentation in the Maillard reaction cascade: isotope labeling studies on the formation of acetic acid by a hydrolytic $\beta$-dicarbonyl cleavage mechanism. J Agric Food Chem 54(18):6667-6676

Dwyer J, Lant P (2008) Biodegradability of DOC and DON for UV/ $\mathrm{H}_{2} \mathrm{O}_{2}$ pre-treated melanoidin based wastewater. Biochem Eng J 42:47-54

Echavarría AP, Pagán J, Ibarz A (2013a) Antioxidant activity of the melanoidin fraction formed from D-glucose and D-fructose with L-asparagine in the Maillard reaction. Sci Agropecu 4:45-54

Echavarría AP, Pagán J, Ibarz A (2013b) Optimization of Maillard reaction products isolated from sugar-amino acid model system and their antioxidant activity. Afinidad LXX, 562, Abril-Junio

Echavarría AP, Pagán J, Ibarz A (2014) Kinetics of color development of melanoidins formed from fructose/amino acid model systems. Food Sci Technol Int 20(2):119-126

Eggleston G, Vercellotti JR (2000) Degradation of sucrose, glucose and fructose in concentrated aqueous solution under constant $\mathrm{pH}$ conditions at elevated temperature. J Carbohydr Chem 19(9):1305-1318

Ghosh M, Verma SC, Mengoni A, Tripathi AK (2004) Enrichment and identification of bacteria capable of reducing chemical oxygen demand of anaerobically treated molasses spent wash. J Appl Microbiol 96:1278-1286

Gonzalez T, Terron MC, Yague S, Zapico E, Galletti GC, Gonzalez AE (2000) Pyrolysis/gas chromatography/mass spectrometry monitoring of fungal-biotreated distillery wastewater using Trametes sp I-62 (CECT 20197). Rapid Commun Mass Spectrom 14:1417-1424

González T, Terrón MC, Yagüe S, Junca H, Carbajo JM, Zapico EJ, Silva R, Arana-Cuenca A, Téllez A, González AE (2008) Melanoidin-containing wastewaters induce selective laccase gene expression in the white-rot fungus Trametes sp. I-62. Res Microbiol 159(2):103-109

Gu FL, Kim J, Abbas S, Zhang XM, Xia SQ, Chen ZX (2010) Structure and antioxidant activity of high molecular weight Maillard reaction products from casein-glucose. Food Chem 120:505-511 
Hayase F (2000) Recent development of 3-deoxyosone related Maillard reaction products. Food Sci Technol Res 6(2):79-86

Hemavanthi KL, Kumar NKH, Jagannath S (2015) Gentotoxic effect of distillery effluent on root tip cells of Allium sativum L. J Appl Biol Biotechnol 3(03):038-041

Hwang C, Jiang Y, Sheu S, Hsieh P, Guo J (2011) Purification and characterization of a novel glucose oxidase-like melanoidin decolorizing enzyme from Geotrichum sp. No 56. Afr J Microbiol Res 5(20):3256-3266

Kadam AA, Kamatkar JD, Khandare RV, Jadhav JP, Govindwar SP (2013) Solid-state fermentation: tool for bioremediation of adsorbed textile dyestuff on distillery industry waste-yeast biomass using isolated Bacillus cereus strain EBT1. Environ Sci Pollut Res 20:1009-1020

Kapley A, Lampel K, Purohit HJ (2001) Rapid detection of Salmonella in water samples by multiplex PCR. Water Environ Res 73:461-465

Kaushik G, Thakur IS (2013) Adsorption of colored pollutants from distillery spent wash by native and treated fungus: Neurospora intermedia. Environ Sci Pollut Res 20(2):1070-1078

Kaushik G, Gopal M, Thakur IS (2010) Evaluation of performance and community dynamics of microorganisms during treatment of distillery spent wash in a three stage bioreactor. Bioresour Technol 101:4296-4305

Kersters K, Devos P, Gillis M, Swings J, Vandamme P, Stackebrandt E (2006) Introduction to the proteobacteria. In: Dworkin M, Falkow S, Rosenberg E, Schleifer KH, Stackebrandt E (eds) The prokaryotes: a handbook on the biology of bacteria. Springer, New York, pp 3-37

Kim SJ, Shoda M (1999) Batch decolorization of molasses by suspended and immobilized fungus of Geotrichum candidum. J Biosci Bioeng 88(5):586-589

Kim SB, Hayase F, Kato H (1985) Decolourisation and degradation products of melanoidin on ozonolysis. Agric Biol Chem 49:785-792

Kumar P, Chandra R (2006) Decolourisation and detoxification of synthetic molasses melanoidins by individual and mixed cultures of Bacillus spp. Bioresour Technol 97:2096-2102

Lau J, Tran C, licari P, Galazzo J (2004) Development of a high celldensity fed-bath bioprocess for the heterologous production of 6-deoxyerythronolide B in Escherichia coli. J Biotechnol 110:95-103

Liakos TI, Lazaridis NK (2014) Melanoidins removal from simulated and real wastewaters by coagulation and electro-flotation. Chem Eng J 242:269-277

Liang Z, Wang Y, Zhou Y, Liu H, Wu Z (2009a) Variables affecting melanoidins removal from molasses wastewater by coagulation/ flocculation. Sep Purif Technol 68(3):382-389

Liang Z, Wang Y, Zhou Y, Liu H (2009b) Coagulation removal of melanoidins from biologically treated molasses wastewater using ferric chloride. Chem Eng J 152(1):88-94

Mahgoub S, Tsioptsias C, Samaras P (2016) Biodegradation and decolorization of melanoidin solutions by manganese peroxidase yeasts. Water Sci Technol 73(10):2436-2445

Martins S, Van Boekel M (2003) Melanoidins extinction coefficient in the glucose/glycine Maillard reaction. Food Chem 83:135-142

Miyata N, Mori T, Iwahori K, Fujita M (2000) Microbial decolourization of melanoidin-containing wastewaters: combined use of activated sludge and the fungus Coriolus hirsutus. J Biosci Bioeng $89: 145-150$

Mohana S, Acharya BK, Madamwar D (2007) Distillery spent wash: treatment technologies and potential applications. J Hazard Mater 163(1):12-25

Nolasco Junior J, De Massaguer PR (2006) Thermal degradation kinetics of sucrose, glucose and fructose in sugarcane must for bioethanol production. J Food Process Eng 29:462-477
Okino LK, Machado KMG, Fabris C, Bononi VLR (2000) Ligninolytic activity of tropical rainforest basidiomycetes. World J Microbiol Biotechnol 16(8-9):889-893

Onyango MS, Kittinya J, Hadebe N, Ojijo VO, Ochieng A (2011) Sorption of melanoidin onto surfactant modified zeolite. Chem Ind Chem Eng Q 17:385-395

Pangallo D, Simonovicova A, Chovanova K, Ferianc P (2007) Wooden art objects and the museum environment: identification and biodegradative characteristics of isolated microflora. Lett Appl Microbiol 45:87-94

Pant D, Adholeya A (2007) Identification, ligninolytic enzyme activity and decolorization potential of two fungi isolated from a distillery effluent contaminated site. Water Air Soil Pollut 183:165-176

Pant D, Adholeya A (2009a) Nitrogen removal from biomethanated spent wash using hydroponic treatment followed by fungal decolorization. Environ Eng Sci 26:559-565

Pant D, Adholeya A (2009b) Concentration of fungal ligninolytic enzymes by ultrafiltration and their use in distillery effluent decolorization. World J Microbiol Biotechnol 25:1793-1800

Raghukumar C, Rivonkar G (2001) Decolourization of molasses spent wash by the white-rot fungus Flavodon flavus, isolated from a marine habitat. Appl Microbiol Biotechnol 55:510-514

Ramezani A, Darzi GN, Mohammadi M (2011) Removal of melanoidin from molasses spent wash using fly ash-clay adsorbents. Korean J Chem Eng 28:1035-1041

Rodriguez E, Pickard M, Vazquez-Duhalt R (1999) Industrial dye decolourisation by laccase from ligninolytic fungi. Curr Microbiol 38:27-31

Santal AR, Singhb NP, Saharan BS (2011) Biodegradation and detoxification of melanoidin from distillery effluent using an aerobic bacterial strain $\mathrm{SAG}_{5}$ of Alcaligenes faecalis. J Hazard Mater 193:319-324

Satyawali Y, Balakrishnan M (2008) Treatment of distillery effluent in a membrane bioreactor (MBR) equipped with mesh filter. Sep Purif Technol 63(2):278-286

Sirianuntapiboon S, Zohsalam P, Ohmomo S (2004) Decolorization of molasses wastewater by Citeromyces sp. WR-43-6. Process Biochem 39:917-924

Tamura K, Stecher G, Peterson D, Filipski A, Kumar S (2013) MEGA6: molecular evolutionary genetics analysis version 6.0. Mol Biol Evol 30(12):2725-2729

Thakkar AP, Dhamankar VS, Kapdnis BP (2006) Biocatalytic decolorisation of molasses by Phanerochaete chrysosporium. Bioresour Technol 97(12):1377-1381

Tiwari S, Gaur R, Singh R (2012) Decolorization of a recalcitrant organic compound (Melanoidin) by a novel thermotolerant yeast, Candida tropicalis RG-9. BMC Biotechnol 12:30

Tiwari S, Rai P, Yadav SK, Gaur R (2013) A novel thermotolerant Pediococcus acidilactici B-25 strain for color, COD, and BOD reduction of distillery effluent for end use applications. Environ Sci Pollut Res Int 20(6):4046-4058

Tiwari S, Gaur R, Singh A (2014) Distillery spentwash decolourisation by a noval consortium of Pedicoccus acidilactici and Candida tropicalis under static condition. Pak J Biol Sci 17(6):780-791

USEPA (2002) The environment protection rules, 3A, Schedule-II, III. U.S. Environmental Protection Agency, Office of research and development, Cincinnati

Verman SR, Delea RC, Tyagi MP, Gupta SP (1974) Studies of characteristics and disposal problem of industrial effluent with reference to ISI standard; part I. Indian J Environ Health 16:289-299

Walford SN (1996) Composition of cane juice. Proc S Afr Sug Technol Ass 70:265-266

Wang H, Qian H, Yao W (2011) Melanoidins produced by the Maillard reaction: structure and biological activity. Food Chem 128:573-584 
Woese CR, Weisburg WG, Hahn CM, Paster BJ, Zablen LB, Lewis BJ, Macke TJ, Ludwig W, Stackebrandt E (1985) The phylogeny of purple bacteria: the gamma subdivision. Syst Appl Microbiol 6:25-33

Yadav S, Chandra R (2012) Biodegrdation of organic compounds of molasses melanoidins (MM) from biomethanated distillery distillery spent wash (BMDS) during the decolourisation by potential bacterial consortium. Biodegradtion 23:609-620

Yadav S, Chandra R (2013) Detection of persistent organic compounds from biomethanated distillery spent wash (BMDS) and their degradation by manganese peroxidase and laccase producing bacterial strains. J Environ Biol 34(4):755-764

Yadav S, Chandra R, Rai V (2011) Characterization of potential MnP producing bacteria and its metabolic products during decolourisation of synthetic melanoidins due to biostimulatory effect of d-xylose at stationary phase. Proc Biochem 46:1774-1784 